\title{
Secretion and Function of Pituitary Prolactin in Evolutionary Perspective
}

\section{OPEN ACCESS}

Edited by:

Giovanne B. Diniz,

Yale University, United States

Reviewed by:

Stanko S. Stojilkovic,

National Institutes of Health (NIH),

United States

Arieh Gertler,

Hebrew University of Jerusalem, Israe

Dave Grattan,

University of Otago, New Zealand

*Correspondence:

Arpád Doboly

dobolyi.arpad@ttk.elte.hu

Specialty section:

This article was submitted to

Neuroendocrine Science,

a section of the journal

Frontiers in Neuroscience

Received: 25 January 2020

Accepted: 19 May 2020

Published: 16 June 2020

Citation:

Dobolyi A, Oláh S, Keller D

Kumari R, Fazekas EA, Csikós V, Renner É and Cservenák M (2020)

Secretion and Function of Pituitary

Prolactin in Evolutionary Perspective.

Front. Neurosci. 14:621.

doi: 10.3389/fnins.2020.00621

\begin{abstract}
Arpád Dobolyi 1,2*, Szilvia Oláh', Dávid Keller², Rashmi Kumari', Emese A. Fazekas', Vivien Csikós ${ }^{1}$, Éva Renner ${ }^{3}$ and Melinda Cservenák ${ }^{1}$

${ }^{1}$ MTA-ELTE Laboratory of Molecular and Systems Neurobiology, Department of Physiology and Neurobiology, Institute of Biology, Eötvös Loránd University, Budapest, Hungary, ${ }^{2}$ Laboratory of Neuromorphology, Department of Anatomy, Histology and Embryology, Semmelweis University, Budapest, Hungary, ${ }^{3}$ Human Brain Tissue Bank and Microdissection Laboratory, Semmelweis University, Budapest, Hungary
\end{abstract}

The hypothalamo-pituitary system developed in early vertebrates. Prolactin is an ancient vertebrate hormone released from the pituitary that exerts particularly diverse functions. The purpose of the review is to take a comparative approach in the description of prolactin, its secretion from pituitary lactotrophs, and hormonal functions. Since the reproductive and osmoregulatory roles of prolactin are best established in a variety of species, these functions are the primary subjects of discussion. Different types of prolactin and prolactin receptors developed during vertebrate evolution, which will be described in this review. The signal transduction of prolactin receptors is well conserved among vertebrates enabling us to describe the whole subphylum. Then, the review focuses on the regulation of prolactin release in mammals as we have the most knowledge on this class of vertebrates. Prolactin secretion in response to different reproductive stimuli, such as estrogen-induced release, mating, pregnancy and suckling is detailed. Reproduction in birds is different from that in mammals in several aspects. Prolactin is released during incubation in avian species whose regulation and functional significance are discussed. Little information is available on prolactin in reptiles and amphibians; therefore, they are mentioned only in specific cases to explain certain evolutionary aspects. In turn, the osmoregulatory function of prolactin is well established in fish. The different types of pituitary prolactin in fish play particularly important roles in the adaptation of eutherian species to fresh water environments. To achieve this function, prolactin is released from lactotrophs in hyposmolarity, as they are directly osmosensitive in fish. In turn, the released prolactin acts on branchial epithelia, especially ionocytes of the gill to retain salt and excrete water. This review will highlight the points where comparative data give new ideas or suggest new approaches for investigation in other taxa.

Keywords: evolution, comparative, neuroendocrinology, hypothalamus, dopamine, osmoregulation, lactation

\section{INTRODUCTION}

Prolactin is an ancient regulatory molecule with diverse regulatory functions (Freeman et al., 2000). Prolactin has been shown to be expressed in a variety of different organs, however, its expression level is highest in the pituitary ( $\mathrm{Bu}$ et al., 2015). It was suggested that in early vertebrates, the expression of prolactin was more diverse, but even in fish, it is already predominantly expressed 
in specific cells of the adenohypophysis, from which prolactin is released into the bloodstream to act as a multifunctional hormone. Based on the structure and receptor type of prolactin, it belongs to the cytokines. Thus, together with growth hormone, it forms a group of pituitary hormones, which are not a 3-51 amino acid long neuropeptides acting on G-protein coupled receptors, but possess 1 transmembrane domain cytokine receptor. In these properties, prolactin and growth hormone are also different from the structure of other peptide and glycoprotein pituitary hormones. Another unique property of prolactin among adenohypophyseal hormones is that it does not have a target endocrine gland, which would mediate its actions but rather it exerts its actions directly via prolactin receptors localized in a variety of different target organs (Grattan, 2015). Most of the major targets of prolactin are epithelial cells, on which prolactin can exert proliferative effects as well as faster gene expression and even faster molecular actions (Aoki et al., 2019). In this paper, we will review the major actions of prolactin in vertebrate taxa. Most knowledge is available in mammals and fish where lactation and osmoregulation are the most established functions of prolactin, respectively (Horseman and Gregerson, 2014). Data are also accumulating in birds where prolactin is critically important in parental behavioral control (Smiley, 2019). The different functions require diverse stimuli for the release of prolactin. Our knowledge is more limited in this aspect of prolactin regulation. An aim of this review is to compare prolactin-related regulations between different vertebrate taxa to generate new research approaches.

\section{PROLACTIN AND THE EVOLUTION OF PROLACTIN GENES}

Prolactin belongs to a gene family that comprises prolactin, growth hormone and somatolactin. The peptide sequences of these proteins exhibit approximately 20\% homologies to each other in teleost species where all 3 of them are present. There are several additional versions of prolactin in specific vertebrate species, which were formed by local gene duplication. Although some reports suggested the presence of prolactin-like peptides in invertebrates, the general agreement is that the whole protein family was formed in chordates. It is known that whole genome duplication occurred 3 times during vertebrate evolution; the first round (1R) at the transition from chordates to vertebrates, the second round $(2 \mathrm{R})$ at the transition from agnathans to gnathostomes, and the third round (3R) after divergence of the teleost lineage. As for the prolactin gene family, however, even ancient chordate species before the $1 \mathrm{R}$ whole genome duplication possessed the three genes (Figure 1). Following $1 \mathrm{R}$ and $2 \mathrm{R}$ whole genome duplications, only one additional gene, prolactin 2 emerged while the teleost specific $3 \mathrm{R}$ whole genome duplication resulted in another gene, somatolactin b. In turn, somatolactin was lost in amniotes, and prolactin 2 was lost in mammals (Ocampo Daza and Larhammar, 2018a). The two different prolactins in teleost fish have similar functions. The prolactins are co-secreted from lactotrophs (Specker et al., 1993) and may bind to the same prolactin receptor albeit with different affinities

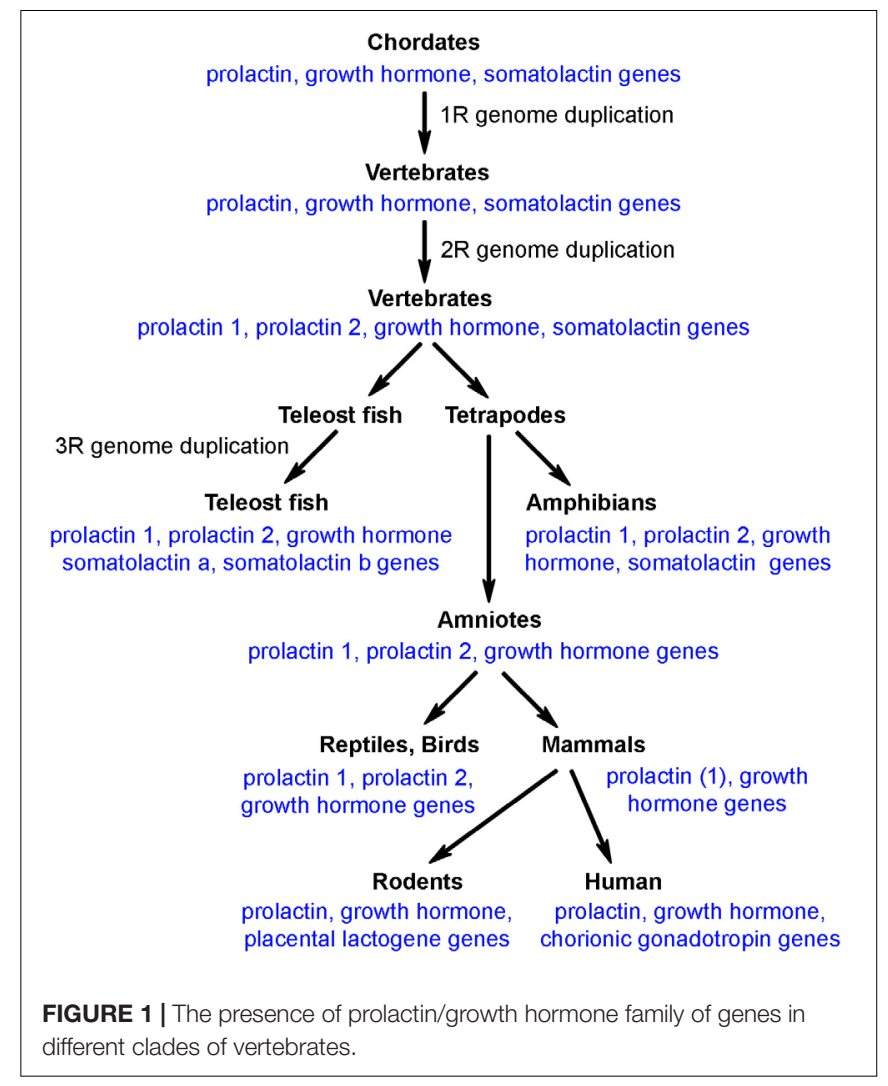

(Auperin et al., 1995). The change in prolactin sequence showed an uneven speed in vertebrate evolution, which is in line with its role in major adaptive events, such as freshwater adaptation, or the development of lactation in mammals. Furthermore, new prolactin-like protein coding genes have developed, which, however, are typically not expressed in the pituitary. For example, rodents possess several placental lactogens (Bridges et al., 1996; Goffin et al., 1996). However, the present review, focuses on pituitary prolactin and mentions other prolactin-related proteins only if necessary for understanding of the functions of pituitaryderived prolactin.

The pituitary itself is an organ unique to vertebrates. In cephalochordates, the pituitary has a homolog, Hatschek's pit, an organ in the epithelial invagination of the oral cavity whose morphology and development is similar to the Rathke's pouch of the vertebrate embryo (Kubokawa et al., 2010). Cells of the Hatschek's pit express some proteins homologous to some adenohypophyseal hormones but not to prolactin (Holland et al., 2008). In vertebrates, the structure of the pituitary is similar in all classes (Sage and Bern, 1971). This structure consists of an anterior lobe, an intermediate lobe and a posterior lobe, or neurohypophysis. The anterior lobe of the pituitary is the adenohypophysis, which contains lactotrophs as well as other types of secretory cells (Bern and Nicoll, 1968). Lactotrophs actually form a more definitive mass within the rostral pars distalis of the adenohypophysis as opposed to the more intermingled localization of lactotrophs with other hormone producing cells in the lungfish and tetrapod pituitary 
(Manzon, 2002). The secretory activity of adenohypophyseal cells is regulated by releasing and inhibitory factors of hypothalamic origin. Tetrapods have a hypophyseal portal system, which is reached by hypothalamic hormones in the median eminence. Fish do not have a median eminence, and the anterior part of the neurohypophysis was suggested to play a similar role in them (Sage and Bern, 1971).

\section{LACTOTROPH CELLS IN THE PITUITARY AND THEIR PROLACTIN RELEASE}

Lactotrophs are located in the anterior lobe of the pituitary. In fish, prolactin secretion from lactotrophs seems to be affected directly by osmolarity as even cultured lactotrophs are sensitive to reduced osmolarity in their extracellular environment and respond to it by increased size and prolactin secretion (Labella et al., 1975; Weber et al., 2004). In mammals, in contrast, lactotrophs spontaneously release prolactin. It has been demonstrated that lactotrophs fired spontaneous plateaubursting action potentials, which generated high amplitude calcium signals due to calcium influx via voltage-gated calcium channels (Van Goor et al., 2001). While different hypothalamic prolactin releasing factors have been proposed in mammals the most compelling evidence is available for thyrotropinreleasing hormone -, it is still a general consensus that prolactin secretion from lactotrophs is only controlled by the inhibitory action of dopamine exerted by D2 dopamine receptors in mammals. The G-protein coupled D2 receptors utilize different signal transduction pathways to inhibit spontaneous prolactin release. They block voltage-gated calcium channels via pertussis toxin sensitive $G_{i / o}$ proteins while also desensitize calcium ion secretion coupling via pertussis toxin insensitive $\mathrm{Gz}$ proteins (Gonzalez-Iglesias et al., 2008). Accordingly, D2 receptor agonists, e.g., bromocriptine, block spontaneous electrical activity of lactotrophs as well as accompanied prolactin release (Auriemma et al., 2019). Therefore, bromocriptine can be used to cease milk production or treat hyperprolactinemia induced by pituitary tumors. In addition, mice lacking the D2 receptor are hyperprolactinemic (Saiardi et al., 1997). Dopamine reaches lactotrophs from the portal circulation of the pituitary, which contains dopamine following its release from dopaminergic neurons located in the arcuate nucleus (A12 dopaminergic cell group in mammals). Additional alternative ways of dopamine reaching lactotrophs have also been suggested, notably dopaminergic neurons located in the periventricular area (A14 dopaminergic cell group in mammals) projecting to the intermediate lobe of the pituitary. Although D2 receptors on lactotrophs play a role in the control of prolactin secretion in birds (Lv et al., 2018), they seem to possess a prolactinreleasing hormone, vasoactive intestinal peptide (VIP) (Tong et al., 1998; Christensen and Vleck, 2008)-Contrary to the lack of active prolactin-releasing mechanisms in mammals. VIP, similar to dopamine, is also released from neurons located in the infundibular/arcuate nucleus (Kosonsiriluk et al., 2008). The mechanism of negative feedback regulation for stable prolactin levels is driven by prolactin itself, which increases the neuronal activity of neuroendocrine dopaminergic neurons (Brown et al., 2012) and also their dopamine synthesis (Arbogast and Voogt, 1995) to reduce prolactin secretion. In birds, the participation of VIP in negative feedback would also make sense as an additional mechanism of feedback inhibition of prolactin release, but the available evidence is scarce (Namken et al., 2017). In mammals, VIP has also been suggested as regulator of prolactin secretion. VIP was found to be synthesized both in the hypothalamus and pituitary (Lam, 1991). In vitro, VIP stimulated prolactin release from lactotrophs (Bjoro et al., 1990). However, its effect was not specific as it also released other pituitary hormones (Lam, 1991). More recently it was suggested that VIP of suprachiasmatic origin could affect circadian rhythm of prolactin secretion (Egli et al., 2004; Kennett et al., 2008), or only some subtypes of lactotrophs could be affected by VIP (Christian et al., 2007), alternatively, VIP could affect proliferation of lactotrophs (Carretero et al., 2006). But most likely, VIP is not a physiological regulator of prolactin secretion in mammals (Phillipps et al., 2019). It is also not established yet if prolactin release in fish is regulated by the hypothalamus. It seems likely that not only osmolarity in the pituitary but other factors play a part in prolactin secretion. Estrogen evoked prolactin release from the marine teleost, sea bream (Sparus aurata L.), and this effect was inhibited by VIP (Brinca et al., 2003). Thus, VIP could be involved in the regulation of prolactin release as it is in avian species but exerts the opposite action by inhibiting the release.

\section{PROLACTIN RECEPTORS AND THEIR SIGNAL TRANSDUCTION}

Prolactin is secreted from the pituitary to the circulation. Prolactin may bind to prolactin-binding proteins, which have been suggested in mammals but not in other taxa (Kline and Clevenger, 2001). Prolactin then exerts its actions by binding to its plasma membrane receptors.

\section{Evolution of Prolactin Receptors}

DNA sequence comparisons as well as synthetic analysis revealed that early vertebrates possessed a common growth hormone/prolactin receptor even after the $2 \mathrm{R}$ tetraploidization event (even though separate growth hormone and prolactin genes were present before $1 \mathrm{R}$ ). The separate prolactin receptor appeared soon after that by gene duplication (Ocampo Daza and Larhammar, 2018b). The teleost-specific 3R tetraploidization resulted in 2 prolactin receptor genes (PrlRa and b), which is characteristic of most teleost fish.

\section{Signal Transduction of Prolactin}

The prolactin receptors all belong to the type I cytokine receptor family (Bole-Feysot et al., 1998). In mammals, there are long, intermediate and short prolactin receptor isoforms generated by alternative splicing (Freeman et al., 2000). All these isoforms are 1 transmembrane domain plasma membrane receptors. Signal transduction requires dimerization of the receptors. The receptors do not have enzyme activity but rather attract adaptor molecules upon prolactin binding to initiate signal transduction. 
There are two major types of signal transduction pathways for the prolactin receptor. The conventional pathway uses a cytosolic tyrosine kinase, Janus kinase 2 (Campbell et al., 1994), which phosphorylates signal transducer and activator (STAT) 5 (Clevenger and Kline, 2001). Phosphorylated STAT5 (pSTAT5) then forms homodimers and acts as a transcription factor to induce the expression of various proteins, e.g., casein milk proteins. An alternative pathway is the mitogen-activated protein (MAP) kinase pathway, which generally mediates the proliferative actions of prolactin (Radhakrishnan et al., 2012).

\section{Expression of Prolactin Receptors in Different Tissues}

Prolactin receptors are expressed in a variety of different organs based on different blotting and PCR technologies. In the fish, the osmoregulatory organs, such as the gills, kidney, and intestine contained the highest amount of prolactin receptor (Lee et al., 2006). In addition, prolactin receptors are also abundant in the brain, liver, gonads, liver, spleen, and present in the heart, muscle, bone, and skin, too (Sandra et al., 2000; Santos et al., 2001). Prolactin receptor has a similarly widespread tissue distribution in other clades, too. In mammals, the long and the short forms of prolactin receptors had similar distribution patterns with the long form dominating in most organs except for the kidney and lung (Ouhtit et al., 1993). More detailed distributional patterns of prolactin receptors within the organs expressing it have also been established, which, for example, indicated particularly high level of prolactin receptors within ionocytes of gill epithelium in fish, or alveolar cells of the mammary gland.

\section{Distribution of Prolactin Receptors in the Brain}

Given the enormously high number of different cell types in the brain and the different functions connected to the nervous system, the distribution of prolactin receptors within the mammalian brain has been in focus for decades. Initial immunolabeling studies demonstrated neuronal expression and a topographical distribution within the brain with high level of prolactin receptor in the anteroventral periventricular nucleus, the medial preoptic area, the paraventricular, and the arcuate nuclei with even more hypothalamic sites becoming visible in lactating rats ( $\mathrm{Pi}$ and Voogt, 2000) with weak labeling in some striatal, thalamic and cortical sites, too. This distributional pattern was confirmed by in situ hybridization histochemistry, which also showed that the short form of the receptor may be present in hypothalamic but also in extrahypothalamic sites (Bakowska and Morrell, 1997, 2003). Modern molecular biological techniques using prolactin receptor-Cre recombinase mice bred with green fluorescent protein reporter mice revealed the precise expression of the long form of the prolactin receptor in the same sites as also described by in situ hybridization histochemistry (Kokay et al., 2018). The sites of signal transduction of prolactin can also be directly examined using pSTAT5 immunohistochemistry, which resulted in the same labeling pattern following injection of exogenous prolactin (Brown et al., 2010; Sjoeholm et al., 2011) or following suckling

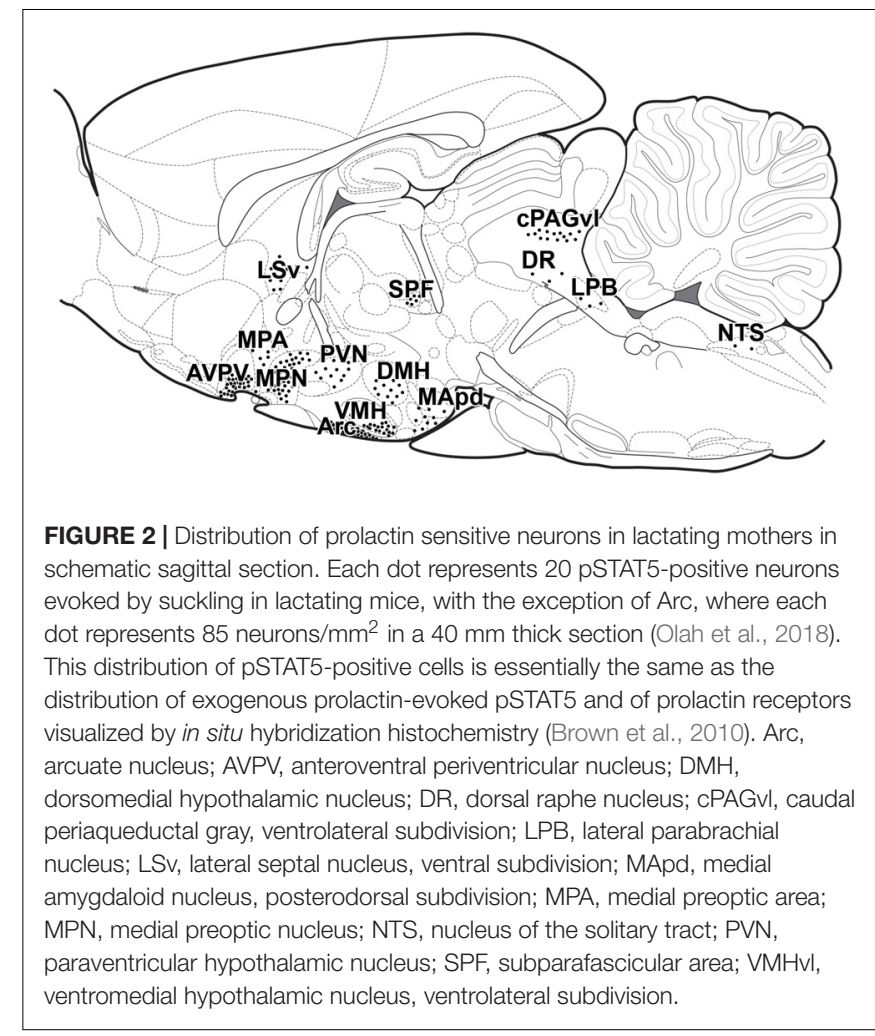

in lactating mice (Olah et al., 2018) as described with the above techniques (Figure 2). Some of these methods cannot properly address the subcellular location of prolactin receptors, e.g., where they are located in relation to synapses. Therefore, techniques, which can address these type of questions, such as immunohistochemistry remain important research tools in the field in the future, too.

\section{REPRODUCTIVE ACTIONS OF PROLACTIN}

The reproductive cycle of animals can be generally divided into sexual and parental phases. Despite the phylogenetic diversity in the specific regulations, it can be claimed that gonadotropins and sexual steroid hormones play pivotal roles in the control of the sexual phase while prolactin is the major regulator of the parental phase (Everett, 1964). Of course, the 2 phases are connected with each other. Indeed, prolactin is released during the luteinizing hormone surge in the estrous cycle, due to increased estrogen levels, which could be a direct pituitary action or a kisspeptinevoked suppression of dopaminergic activity (Szawka et al., 2011; Grattan and Szawka, 2019). The role of the prolactin released during estrous is not well established to date (Phillipps et al., 2019) as it does not seem to affect female sexual behavior (Witcher and Freeman, 1985). Prolactin secretion is also induced by mating, both in males and females, and a characteristic prolactin secretory pattern appears during pregnancy. Our knowledge is highly limited in nonmammalian species regarding estrogen- 
or mating-induced prolactin release. Furthermore, dopamine release under these circumstances varies even within mammals, as discussed below.

\section{Prolactin Released During Mammalian Pregnancy}

Mating induces prolactin secretion (Exton et al., 2001). Information on mating is probably conveyed to the hypothalamus in a neuronal pathway similar to that involved in suckling (described below) as both transfer somatosensory information from the spinal cord to the same hypothalamic site, the dopaminergic neurons in the arcuate nucleus. The role of mating-induced prolactin secretion is not known (Voogt et al., 2001). In males, it could contribute to the sexual refractory period or the formation of parental motivation. In females, mating-induced release may initiate the characteristic pattern of prolactin secretion during pregnancy. This secretory pattern can be highly different depending on the species. In humans, progesterone synthesis in the corpus luteum is maintained by chorionic gonadotropin of placental origin. In contrast, prolactin maintains the corpus luteum in rodents, which requires an immediate high concentration of prolactin in the serum (Phillipps et al., 2019). To this end, prolactin is released from the pituitary twice a day (Gunnet and Freeman, 1983). This secretory pattern is probably triggered by mating and lasts for 1213 days if the animal is pseudopregnant, e.g., following artificial vaginocervical stimulation (Gunnet and Freeman, 1984). In turn, prolactin secretion from the pituitary ceases at approximately 9-10 days of pregnancy, as it is terminated by negative feedback due to lactogens of placental origin (Goffin et al., 1996). The placenta is fully functional by that time of pregnancy, and rodents have expanded the number of genes encoding prolactin-like proteins, which are expressed in the placenta (Soares et al., 2007). Some of these placental lactogens act on the prolactin receptor, therefore, their high serum concentration inhibits prolactin release from the pituitary by activating dopaminergic neurons in the arcuate nucleus via the prolactin receptor expressed in these neurons (Goffin et al., 1996). In contrast to rodents, human prolactin levels rise gradually during pregnancy, which is likely a steroid driven process (Phillipps et al., 2019). The major role of prolactin and placental lactogens in late pregnancy is mammopoesis. This function can be well assessed in mice lacking prolactin or prolactin receptor: mammary glands do not have proper side branching and alveologenesis, of which only the former can be rescued by progesterone (Horseman and Gregerson, 2014). These actions of prolactin are complex as they are mediated by receptor activator of nuclear factor kappa-B (RANK) present in secretory cells of the alveolar epithelium. RANK ligand is released from prolactin-sensing cells in the alveolar epithelium to mediate paracrine actions (Fernandez-Valdivia et al., 2009). The pregnancy of rats lasted for 22 days. Approximately 1 day before parturition, a prolactin surge emerges probably because progesterone is reduced at this point, which helps dopaminergic neurons escape feedback stimulation, even though placental lactogen levels are still high. It was proposed that the dopamine content of dopaminergic neurons in the arcuate nucleus is reduced (Andrews and Grattan, 2003), possibly producing encephalin instead of dopamine (Yip et al., 2019). The function of this release of prolactin before parturition is not clearly established because prolactin effects required during pregnancy, such as lactogenesis, adaptation of the brain for maternal behavior, or increased insulin secretion via prolactin receptors in the beta cells of the pancreas to avoid hyperglycemia can all be performed by placental lactogens.

\section{Prolactin Released in the Postpartum Period in Response to Suckling in Mammals}

Serum prolactin levels are generally high in the postpartum period (Crowley, 2015). Although the proliferation and hypertrophy of lactotrophs are required for their maintenance (Le Tissier et al., 2015), some processes are required to prevent the negative feedback caused by prolactin itself. The mechanisms of these alterations during lactation have not been elucidated to date. The phenotypic changes described above for late pregnancy (that is an induced enkephalin production by tuberoinfundibular dopaminergic neurons) could be involved. In addition, insulinlike growth factor-1 (IGF-1) has also been suggested to play a role (Dobolyi and Leko, 2019). Prolonged intracerebroventricular IGF-1 was shown to stimulate dopamine secretion in the mediobasal hypothalamus and inhibit prolactin secretion from the pituitary (Leko et al., 2017a). In turn, a binding protein of IGF-1, IGF-binding protein-3 (IGFBP-3) is induced dramatically during lactation specifically in the arcuate nucleus (Leko et al., 2017b). Therefore, IGFBP-3 may be able to sequester IGF-1 from around dopaminergic neurons thereby eliminating the local stimulatory effects of otherwise elevated IGF-1 on dopaminergic neurons (Leko et al., 2017b).

The above mentioned, and potentially other mechanisms preventing feedback inhibition of prolactin levels are necessary for elevated prolactin level during lactation. However, the major stimulus that induces prolactin secretion in mothers, is suckling by the pups. Suckling-induced prolactin release was measured in several species. The experimental paradigm most often used in rats includes removal of the pups for $4 \mathrm{~h}$ from the dam, during which her serum prolactin levels decrease to a basal minimum level (Neill and Nagy, 1994; Nagy et al., 2005). When the litter is given back to the mother, suckling starts almost immediately. Serum prolactin increases approximately 60 fold, and the maximum level is reached at $30 \mathrm{~min}$ following the beginning of suckling (Cservenak et al., 2013). The increased prolactin level is a consequence of reduced dopamine action from the arcuate nucleus (Phillipps et al., 2019). Therefore, tuberoinfundibular dopaminergic neurons must be inhibited by somatosensory stimulus of the nipples. Early studies suggested that this pathway runs ventromedial to the medial geniculate body because microstimulation of this brain area evoked lactogenesis (Tindal and Knaggs, 1969) (Figure 3A). We found neurons expressing tuberoinfundibular peptide of 39 residues (TIP39) in the same location (Dobolyi et al., 2003b) (Figure 3B). TIP39 belongs to the parathyroid hormone family of peptides, which is most abundantly expressed in the brain and is not known 


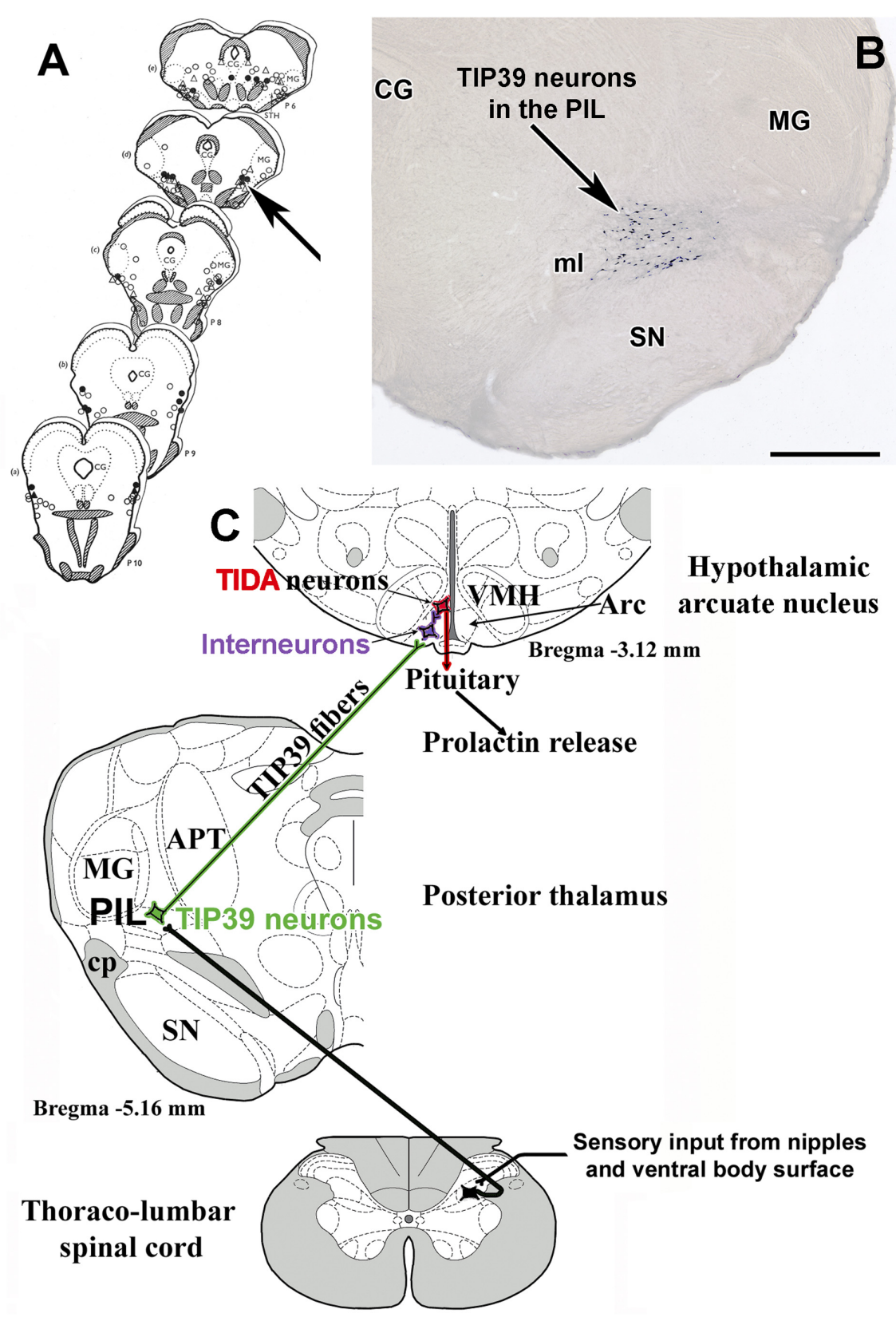

FIGURE 3 | Brain sites whose microstimulation can evoke lactogenesis (A) are compared to the position of TIP39 neurons (B) in the medial subdivision of the posterior intralaminar complex of the thalamus (PIL). (C) The proposed neuronal pathway of suckling-induced prolactin release containing TIP39 neurons in the PIL, which project to the arcuate nucleus. Arrows indicate corresponding brain areas. CG, central gray; MG, medial geniculate body; ml, medial lemniscus; SN,

substantia nigra. Scale bar $=1 \mathrm{~mm}$.

to play any role in calcium homeostasis as other members of the peptide family (Suarez-Bregua et al., 2017). Based on previous topographical characterization of the part of the brain expressing TIP39 (Ledoux et al., 1987), we called the position of TIP39 neurons in the medial subdivision of the posterior intralaminar complex of the thalamus (PIL) (Dobolyi et al., 2010). These neurons were activated in response to suckling and markedly increased their TIP39 expression during lactation (Cservenak et al., 2010). Furthermore, the neurons were shown to project to the arcuate nucleus (Dobolyi et al., 2003a), which contains the receptor of TIP39, the parathyroid hormone 2 receptor (PTH2R) (Usdin et al., 2003) in mice (Faber et al., 2007), rat (Dobolyi et al., 2006), and humans (Bago et al., 2009). Injecting a PTH2R antagonist into the lateral ventricle or expressing it with a virus infecting neurons in the vicinity of the arcuate nucleus markedly reduced suckling induced prolactin release suggesting the prolactin-inducing action of TIP39 (Cservenak et al., 2013) (Figure 3C). TIP39 neurons are likely glutamatergic based on 
electron microscopic and double labeling studies (Cservenak et al., 2017). Glutamate released from these neurons could also be involved in mediating prolactin release. The role of these thalamo-hypothalamic neurons is also consistent with the finding that the pathway, along which projections of TIP39 neurons reach the hypothalamus within the zona incerta (Palkovits et al., 2010), overlaps with the locations of microstimuli evoking lactogenesis rostral to the area ventromedial to the medial geniculate body (Tindal and Knaggs, 1972). Interestingly, stimulation of the preoptic area of the hypothalamus also elicited prolactin secretion. It was interpreted that olfactory information could influence prolactin secretion by that route (Tindal and Knaggs, 1977). In turn, it is also possible that retrograde activation of TIP39 neurons, whose major target is the preoptic area (Cservenak et al., 2017), could also contribute to the stimulatory effect of the preoptic area on prolactin secretion.

The pathway relaying in the PIL (Figure 3C) may also convey the effects of suckling to forebrain sites other than the arcuate nucleus to release prolactin, as suckling induced c-fos expression not only in the PIL (Lin et al., 1998) but also in a variety of different brain regions where PIL neurons project (Li et al., 1999; Lonstein and Stern, 1999). Indeed, the PTH2 receptor was identified in the preoptic area, the paraventricular and dorsomedial hypothalamic nuclei, and the lateral septum (Dobolyi et al., 2006, 2012) and TIP39 terminals were shown to innervate oxytocin neurons in the paraventricular nucleus (Dobolyi et al., 2018) and galanin neurons in the preoptic area (Cservenak et al., 2017) known to control maternal behaviors (Wu et al., 2014).

The functions of prolactin in the postpartum period are numerous. The most well established one is maintaining lactation by acting on mammary epithelial cells. Thereby, prolactin released from a suckling bout enables the mammary gland to further maintain milk production for the next suckling bout via effects of the released prolactin, so in a sense, the pups order their next meal via suckling-induced prolactin release (Phillipps et al., 2019). In addition to lactation, prolactin exerts a variety of different actions in mothers (Bridges and Grattan, 2019) including stimulation of the immune system (Borba et al., 2019) and important effects in the brain by penetrating through the blood-brain barrier (Brown et al., 2016) to reach its multiple targets expressing prolactin receptors in the brain (Bakowska and Morrell, 1997; Kokay et al., 2018) (Figure 2). Prolactin contributes to the increased maternal food intake (Sauve and Woodside, 1996; Naef and Woodside, 2007), lactational anestrus (Grattan and Szawka, 2019), and the induction of maternal behaviors (Brown et al., 2017). These actions are conveyed by the prolactin receptor, although it is established only in some cases which prolactin action is mediated by which location (Table 1). While prolactin is the major maternal hormone affecting the brain in mammals, the brain functions of mothers are also affected by incoming sensory inputs, primarily from the pups. Pups are known to activate a variety of different brain centers, which can be identified at the cellular level using the $\mathrm{c}$-fos technique. The hormonal and neuronal inputs have to support each other to form the proper adaptive responses including maternal behaviors. Their interaction was addressed by double labeling comparing prolactin activated (pSTAT5-positive) versus directly suckling activated (c-fos-positive) brain areas and neurons. Surprisingly, only a relatively small portion of neurons were affected by both stimuli (Olah et al., 2018), suggesting that prolactin provides different types of information for the maternal adaptation of the brain than direct neuronal inputs arriving primarily from the suckling stimulus.

Suckling-induced prolactin release can be prevented by dehydration of the mother. Drinking high salt $(2.5 \%)$ water for a day reduced suckling-induced prolactin release the following day (Nagy et al., 1992). Acute hyperosmolarity evoked by intraventricular injection of $0.5 \mathrm{ml} 10 \%$ saline within a suckling bout immediately blocked prolactin release. The blockade of suckling in a hyperosmotic state makes sense as a lactating mother loses a large amount of water during milk production. It is not known whether lactotrophs themselves would be osmoreceptors in mammals; therefore, it is more likely that osmoreceptor cells in the preoptic area convey information on serum osmolarity and blood volume to them, probably via dopaminergic neurons, as both acute and chronic effects of high saline concentrations could be blocked with dopamine receptor antagonists (Nagy et al., 1992). When released, prolactin has antidiuretic action to replace lost salt and water by nursing. Prolactin can directly act on thirst centers to increase water intake and on renal tubule cells in the kidney to increase salt and water retention (Morrissey et al., 2001), and its indirect action via anti-diuretic hormone (ADH) was also demonstrated (Walker et al., 2001). In addition, $\mathrm{ADH}$ could also be increased via the suckling stimulus independent of prolactin (Suzuki et al., 2000).

\section{Prolactin Released During Incubation in Birds}

The serum prolactin level is increased in birds during brooding (Kuwayama et al., 1992), and its level correlated with brooding behavior (Smiley and Adkins-Regan, 2016). In fact, an early prolactin surge is responsible for the formation of a brood patch, a defeathered area on the belly skin, which has an abundant blood supply to effectively transfer heat toward the eggs (Ohkubo, 2017). The role of elevated prolactin is likely to be related to incubation behavior (Smiley, 2019), as prolactin administration can induce brooding behavior (Youngren et al., 1991), while reducing prolactin, e.g., by immunization against it, leads to the cessation of incubation (March et al., 1994). The incubation-promoting effects of prolactin are likely to be mediated via prolactin receptors in the preoptic area (Youngren et al., 1989). In addition, prolactin may also contribute to the increased aggressive and defensive behaviors of incubating birds (Romanov et al., 2002) and to the decline in gonadal function by inhibiting gonadotropin-releasing hormone-producing neurons (Rozenboim et al., 1993). Our knowledge of the time course of changes in prolactin levels and actions in the incubation period is not good. It would be interesting to know how fast the prolactin level decreases if the parent is removed from the nest and how fast prolactin rises when allowed to incubate again.

The mechanism by which prolactin is induced by incubation or for incubation is not fully understood. In birds, dopamine 
TABLE 1 | The proposed brain functions of prolactin mediated by prolactin receptors localized in different brain regions.

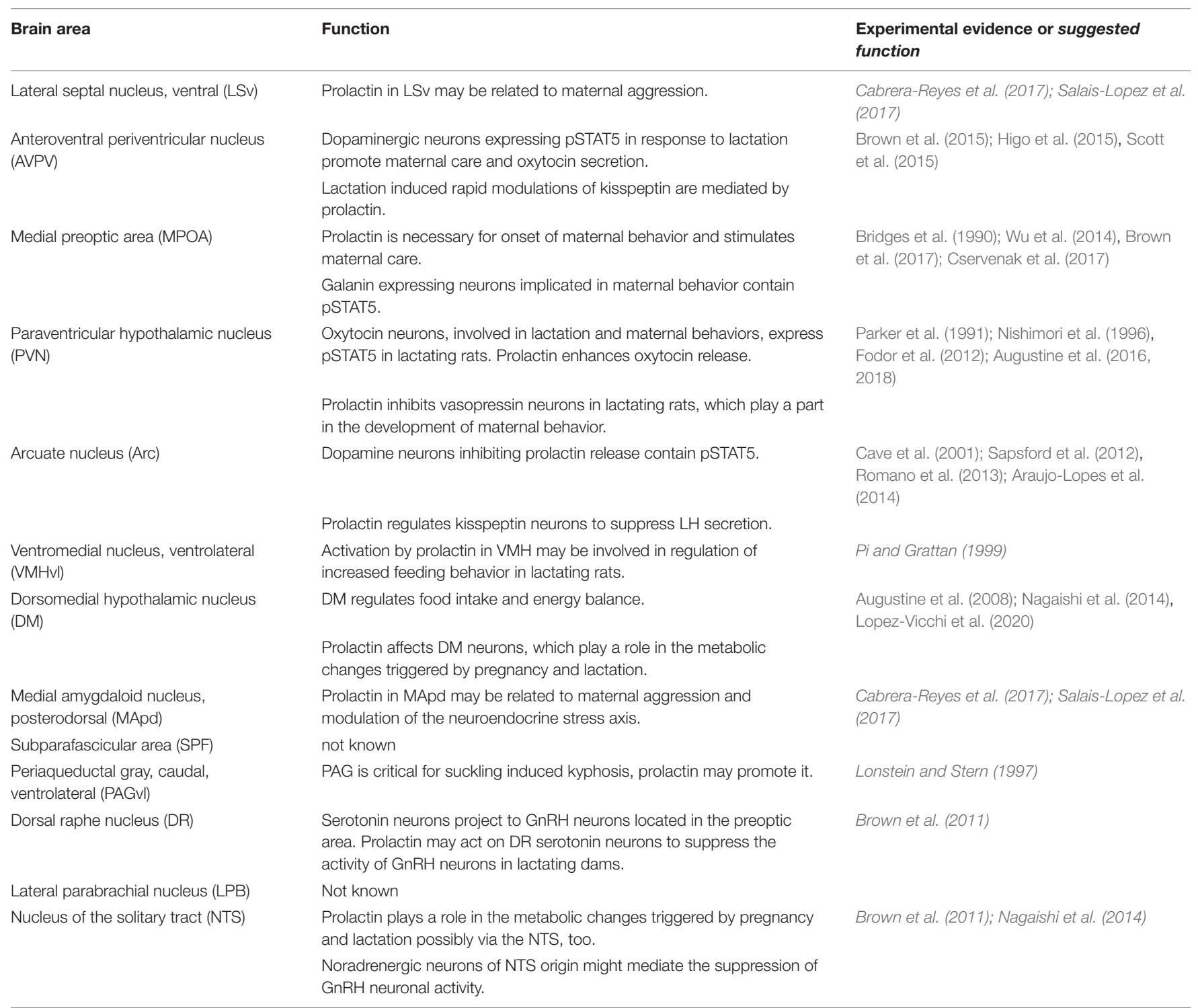

The references written in italics represent only presumed or suggested functions.

can inhibit spontaneous prolactin release from lactotrophs via D2 receptors (Christensen and Vleck, 2008), similar to mammals. However, dopamine also has a stimulatory action via D1 receptors best established in the turkey (Bhatt et al., 2003; Chaiseha et al., 2003) but also in other avian species (Xu et al., 2010). Action via D1 receptors can stimulate hypothalamic neurons expressing VIP (Sartsoongnoen et al., 2008), which acts as a prolactin-releasing hormone in avian species (Proudman and Opel, 1988; Kosonsiriluk et al., 2008). It is unlikely that sexual hormones elicit prolactin release during incubation because increased prolactin levels are found even in ovariectomized birds during incubation. Thus, it is plausible that somatosensory input from the eggs itself can evoke prolactin secretion via neuronal pathways (Massaro et al., 2007). Indeed, swapping eggs from the parents leads to reduced serum prolactin levels (Sinpru et al., 2018). The potential neuronal pathways involved have not been revealed to date. It is not possible that TIP39 plays a role in prolactin release in avian species as it does in mammals because the gene encoding this peptide is missing in birds, even though it is present in all other vertebrate taxa (On et al., 2015), but a homologous neuronal pathway could be involved. Furthermore, it would be interesting to learn whether osmolarity affects prolactin release in birds during incubation as it does during lactation in mammals. However, this question has not been addressed to date, even though it is reasonable that dehydration contributes to the cessation of actual incubation driven by both thirst and a reduced parental motivation due to reduced prolactin level.

In addition to brooding behavior, many avian species, the altricial birds, also show parental behavior in the form of feeding the nestlings (regurgitation) in the posthatching period. Since prolactin level is not particularly high in the posthatching 
period, feeding behavior may not depend on prolactin in most avian species even though the reduction of prolactin following hatching is slower in altricial as compared to precocial birds (Lea and Sharp, 1991) and prolactin level correlated with individual differences in parental behavior in the passerine zebra finch (Smiley and Adkins-Regan, 2016). In turn, rearing behavior in the posthatching period may be induced by tactile stimulation by nestlings in combination with visual or auditory inputs (RichardYris et al., 1998). These inputs are likely mediated toward lactotrophs for prolactin secretion by VIP neurons in the arcuate nucleus as during incubation (Buntin et al., 1991). Tactile, visual and auditory inputs lead to direct neuronal activation of parental brain centers in zebra finch (Fazekas et al., 2020). To date, the interconnection of these activated cells with those sensitive to prolactin has not been established in birds as in mice (Olah et al., 2018), despite the availability of pSTAT5 immunolabeling in birds (Buntin and Buntin, 2014). In addition to a presumed role of prolactin in parenting behavior in birds (Buntin et al., 1991), the hormone may have an additional, specific role in avian species that produce crop milk (Wan et al., 2019). In fact, prolactin was originally discovered by its ability to induce crop milk production in the pigeons. Still, the mechanism of prolactin secretion for crop milk production has not yet been established. Microstimulation experiments suggested that the preoptic area may be involved in crop milk production while direct stimulation of the mediobasal hypothalamus including the median eminence, had no effect (Kanematsu, 1980).

\section{The Roles of Prolactin in Fish Parenting}

Parental behaviors appear in about 30\% of teleost fish (Royle et al., 2014). Interestingly, in these species, the males provide parental care somewhat more often than the females (Reynolds et al., 2002). Although parental behaviors have various forms in fish, the most common forms include nest building and egg (or embryo) attendance. The latter not only protects the eggs from predators but fanning also aerates the eggs and frees them from debris (Rosenblatt, 2003). Although the available knowledge on the control of these behaviors is scarce, some recent data indicated the potential involvement of prolactin (Whittington and Wilson, 2013). Prolactin implants increased nurturing behavior in bluegill (Lepomis macrochirus) (Cunha et al., 2019) and also in three-spined stickleback (Gasterosteus aculeatus) (de Ruiter et al., 1986). Prolactin level may rise during spawning and remains elevated during parental care in cichlid fish (Oreochromis niloticus) (Tacon et al., 2000). The mechanism how prolactin in induced in unknown at present although simple cues as sensory inputs from the eggs are a likely candidate for fanning (Dulac et al., 2014). It should also be mentioned that data arguing against a role of prolactin in fish parenting are also available (Bender et al., 2008).

\section{OSMOREGULATORY ACTIONS OF PROLACTIN}

Osmoregulation is a complex process that includes a variety of different regulatory hormones and systems including prolactin

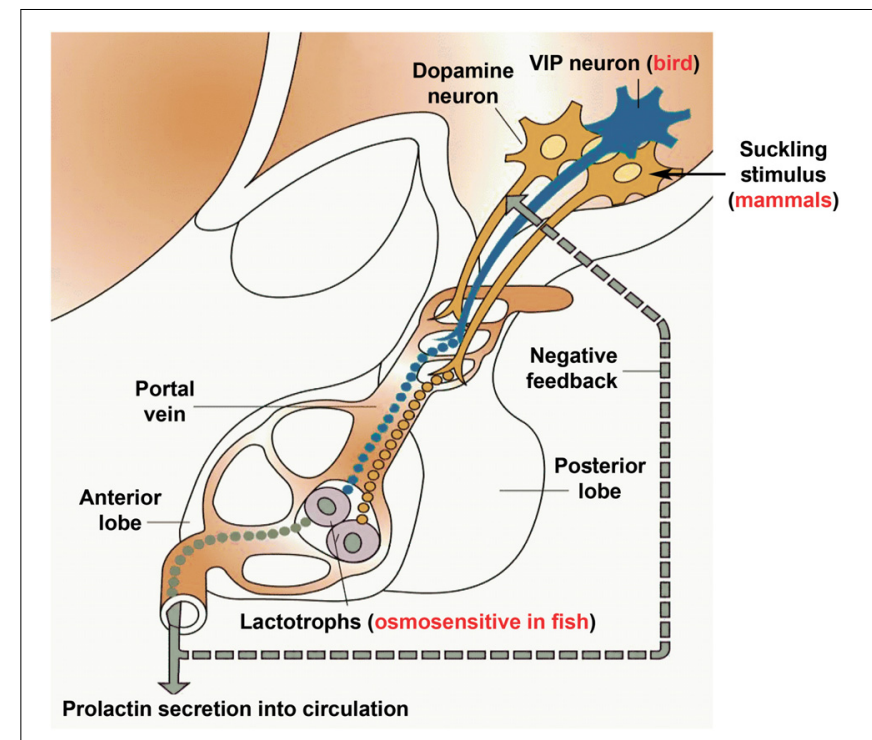

FIGURE 4 | Schematics on the control of prolactin secretion. Prolactin releasing factor, which is truly established only in birds to be vasoactive intestinal polypeptide (VIP), reaches the anterior lobe of the pituitary via the portal circulation to evoke prolactin secretion from the prolactin-producing lactotrophs located in the pituitary. In contrast, prolactin release in fish is most profoundly driven by hyposmolarity sensed by the lactotrophs themselves. In contrast, mammalian lactotrophs release prolactin spontaneously, and the regulation takes place by inhibition, which is carried out by dopamine released from dopaminergic neurons located in the mediobasal hypothalamus. The inhibition of prolactin secretion by dopamine is likely present in all vertebrate taxa. In turn, suckling-induced prolactin secretion is characteristic of mammals only, in which suckling stimulus of the pups is conveyed to dopaminergic neurons in a classic neuroendocrine reflex to stimulate prolactin release according to the need of the pups. The clade-specific features were added to a modified version of the basic scheme (Loipez et al., 2003).

but also renin-angiotensin, anti-diuretic hormone, aldosterone, and atrial natriuretic peptide (Takei et al., 2014). These endocrine components of the regulatory system are relatively conserved in vertebrates despite the differing needs of various animals (the major difference between fish and mammals being the lack of involvement of aldosterone in fish), while the neuronal components of osmoregulation show remarkable differences. Notably, in mammals, forebrain circumventricular organs, such as the vascular organ of the lamina terminalis and the subfornical organ play pivotal roles in sensing both plasma osmolarity and plasma hormone content, most importantly angiotensin II levels (McKinley and Johnson, 2004). These organs convey this information toward thirst centers of the cerebral cortex as well as toward neurohypophyseal neurons synthesizing antidiuretic hormone $(\mathrm{ADH})$. $\mathrm{ADH}$ neurons are themselves osmosensors, which secrete $\mathrm{ADH}$ in response to hyperosmolarity (Bourque and Oliet, 1997). Teleost fish do not have a subfornical organ and the role of the vascular organ of the lamina terminalis is not known in osmoregulation (Katayama et al., 2018). They may be able to respond to angiotensin II detected through the area a postrema (Nobata et al., 2013), a circumventricular organ in the hindbrain. However, the major regulator of their drinking in vagal input from peripheral receptors 
(Mayer-Gostan and Hirano, 1976). These differences between clades may simply is a consequence of forebrain development in mammals, which better allows reconciliation of drinking with other behaviors. Alternatively, the different requirement associated terrestrial environment created the new type of osmoregulatory systems. Indeed, terrestrial animals need to retain water while fish have to deal with the difference in their ionic composition from their environment with which they are in direct contact. Generally, the environment of fish can be freshwater or saltwater, which requires very different regulations. Furthermore, there are euryhaline species that can live in both fresh and seawater, as they migrate or live in brackish water. The major difference between fresh and seawater adaptation of fish is that in the gills, they actively excrete salt in seawater while actively take up salt in fresh water. In addition, fish drink much more in seawater than in fresh water (Takei et al., 2014). Prolactin was shown to play a role in freshwater adaptation as first demonstrated in killifish (Fundulus heteroclitus), a species that could survive following hypophysectomy in fresh water only in the presence of external prolactin (Pickford and Phillips, 1959). More recently, strong evidence came from zebrafish models lacking the prolactin gene: the larvae survived to adulthood in brackish but not in egg water (Shu et al., 2016). This role of prolactin is widespread in euryhaline fish but not ubiquitous, as catfish and salmonids can survive in fresh water following hypophysectomy without prolactin (Hirano, 1986). Although it is possible that the latter species produce prolactin outside of the pituitary as lactotrophs could be located in other locations in relatively primitive eels (Sakamoto and McCormick, 2006). Nevertheless, all teleost species have pituitary with lactotrophs in their anterior lobe; therefore, it is more likely that other osmoregulatory systems can provide freshwater adaptability in these species.

Prolactin exerts its regulatory function in all branchial epithelia, including the gill, kidney, urinary bladder, and gastrointestinal tract (Takei et al., 2014). In fish, the major osmoregulatory organ is the gill where ionocytes are located for water and ion transport while the kidney has the most important osmoregulatory function in mammals (Manzon, 2002). Prolactin may be able induce the proliferation of specific types of ionocytes, which can remove water and take up ions (Hiroi and McCormick, 2012). While prolactin is among the osmoregulatory hormones with relatively slower actions in general, it is also able to induce and stimulate ion transporters, such as $\mathrm{Na}^{+} / \mathrm{Cl}^{-}$cotransporter and the $\mathrm{Na}^{+} / \mathrm{K}^{+}$pump (Breves et al., 2014) via its receptors expressed in ionocytes (Santos et al., 2001). It is also under investigation how the 2 types of prolactin receptors ( $a$ and $b$ ) both expressed in osmoregulatory epithelia of several teleost species support each other's actions. Less evidence is available but it is still likely that prolactin can inhibit aquaporins, e.g., aquaporin 3 , which is known to be involved in freshwater adaptation (Lignot et al., 2002; Breves et al., 2016), and induce tight junction forming cadherins to reduce water uptake in the gills. Our knowledge is more limited on potential action of prolactin on teleost kidney, bladder or inhibition of drinking, which are all potential sites of action. Furthermore, the osmoregulatory function of prolactin is less pronounced in mammals unless we consider its effect on milk production as an osmoregulatory action. Milk contains high amount of fluid as well as sodium ion. Old literature suggested water retention ability of prolactin, however, it was shown to be caused by contamination with ADH (Keeler and Wilson, 1976). More recent experiments demonstrated increased sodium and chloride retention by prolactin (Greenlee et al., 2015) while natriuretic effect in mammals by acting on the $\mathrm{Na}^{+} / \mathrm{K}^{+}$pump via local dopaminergic system in the proximal renal tubules has also been reported (Ibarra et al., 2005). The effect of prolactin on the kidney function of birds is also not known. However, an interesting stimulatory effect of prolactin has been reported on the duck nasal salt gland, an important avian salt excretory organ (Peaker et al., 1970).

The secretion of prolactin in response to changes in osmolarity is less well studied than its osmoregulatory actions. Nevertheless, it has been demonstrated that hyposmolarity evokes prolactin release from the pituitary of teleost fish and an increase in prolactin gene expression also takes place (Lee et al., 2006; Fuentes et al., 2010). It seems likely that lactotrophs themselves are osmosensitive in fish and release prolactin in response to the hypoosmotic local environment (Kwong et al., 2009; Watanabe et al., 2009; Seale et al., 2012). Furthermore, the prolactin secretion as an osmotic response is not affected by pharmacological blockade of dopamine receptors (Liu et al., 2006). Evidence is available that cultured lactotrophs react to reduced osmolarity by prolactin secretion and that it is accompanied by increased cell size of the lactotrophs (Weber et al., 2004). In lactotrophs from Tilapia, the increased cell volume was blocked by aquaporin inhibitors (Watanabe et al., 2009). Given that aquaporin 3 is present in Tilapia lactotrophs (Watanabe et al., 2005), its involvement in water intake of the cells is likely. The increased volume may activate the transient receptor potential-vanilloid (TRPV) 4 receptor, a stretch-activated calcium channel (Watanabe et al., 2002), and the resulting elevated intracellular calcium level leads to prolactin release (Seale et al., 2012). A positive feedback of prolactin has also been suggested to increase the response (Yamaguchi et al., 2016). For long-term adaptation to fresh water, prolactin expression in tremendously increased while aquaporin 3 and TRPV 4 expression are reduced for sensitization of prolactin secretion (Seale et al., 2012). In contrast to fish, there is no compelling evidence on the direct osmosensitivity of lactotrophs in mammals or in other vertebrate taxa. The mammals have osmosensitive cells in the vascular organ of the lamina terminalis and the subfornical organ (McKinley and Johnson, 2004). Neuronal output from these preoptic hypothalamic regions can reach vasopressin neurons in the paraventricular nucleus and thirst centers of the brain. It seems likely that dopaminergic neurons in the mediobasal hypothalamus regulating prolactin secretion from lactotrophs also receive information on osmolarity from the same preoptic receptor cells as hyperosmolarity prevented suckling-induced prolactin release but dopamine receptor antagonists could block the effect of hypoosmolarity as discussed above (Nagy et al., 1992). On the other hand, it has not been addressed in detail whether other types of prolactin release, e.g., during pregnancy or stress can also be inhibited by hyperosmolarity in the pituitary 
in tetrapods although different effects of osmotic inhibition on differently elicited prolactin release have been reported (Dohanics et al., 1994). It is also not known if prolactin release from mammalian lactotrophs are influenced by osmolality of its environment physiologically. Some early results indicated direct osmoreceptive lactotrophs in the mammalian pituitary (Labella et al., 1975; Lorenson and Jacobs, 1987). More recently, it was found that sub-physiological hypotonicity elicited transient release followed by sustained depression of prolactin release from perfused rat lactotrophs (Jorgacevski et al., 2008). The role of osmolality in prolactin secretion of birds is also not established even though it would also be interesting to address whether prolactin secretion during incubation in birds can be prevented by hyperosmolarity. It would make sense if the bird parent would stop incubating and go drinking when hyperosmolarity occurs.

\section{CONCLUSION}

Prolactin is a vertebrate-specific hormone whose functions have been studied for a long time. Indeed, immense knowledge has accumulated on prolactin secretion and function in a variety of different species. Thus, prolactin represents an exciting opportunity for evolutionary neuroendocrinology as its functions are compared between the different species and even different classes of vertebrates. For example, prolactin, a major osmoregulator in fish turned into a hormone that regulates lactation in mammals. In fact, both of these functions require the action of prolactin on epithelial cells, both as far as their proliferation and the control of their transport processes. Another intriguing change is the parental behavioral action of prolactin, which already appears in fish (Cunha et al., 2019) but becomes prominent in birds and mammals. In both classes, parental care has different forms, such as brooding and

\section{REFERENCES}

Andrews, Z. B., and Grattan, D. R. (2003). Opioid receptor subtypes involved in the regulation of prolactin secretion during pregnancy and lactation. J. Neuroendocrinol. 15, 227-236. doi: 10.1046/j.1365-2826.2003.00975.x

Aoki, M., Wartenberg, P., Grunewald, R., Phillipps, H. R., Wyatt, A., Grattan, D. R., et al. (2019). Widespread cell-specific prolactin receptor expression in multiple murine organs. Endocrinology 160, 2587-2599. doi: 10.1210/en.2019-00234

Araujo-Lopes, R., Crampton, J. R., Aquino, N. S., Miranda, R. M., Kokay, I. C., Reis, A. M., et al. (2014). Prolactin regulates kisspeptin neurons in the arcuate nucleus to suppress lh secretion in female rats. Endocrinology 155, 1010-1020. doi: 10.1210/en.2013-1889

Arbogast, L. A., and Voogt, J. L. (1995). Hypoprolactinemia decreases tyrosine hydroxylase activity in the tuberoinfundibular dopaminergic neurons acutely by protein dephosphorylation and chronically by changes in gene expression. Endocrine 3, 801-806. doi: 10.1007/bf02935684

Augustine, R. A., Bouwer, G. T., Seymour, A. J., Grattan, D. R., and Brown, C. H. (2016). Reproductive regulation of gene expression in the hypothalamic supraoptic and paraventricular nuclei. J. Neuroendocrinol. 28, 1-12.

Augustine, R. A., Ladyman, S. R., and Grattan, D. R. (2008). From feeding one to feeding many: hormone-induced changes in bodyweight homeostasis during pregnancy. J. Physiol. 586, 387-397. doi: 10.1113/jphysiol.2007.146316

Augustine, R. A., Seymour, A. J., Campbell, R. E., Grattan, D. R., and Brown, C. H. (2018). Integrative neuro-humoral regulation of oxytocin neuron activity in pregnancy and lactation. J. Neuroendocrinol. 30, 1-15. nursing behaviors. Other effects of prolactin, such as inhibiting gonadotropins is also maintained in a variety of different taxa. Evolutionary comparison of the regulation of prolactin secretion is also instructive. Direct osmosensitivity of lactotrophs is characteristic only of fish; however, hyperosmolarity also inhibits prolactin release in mammals, and research investigating this question is also proposed in birds. The inhibitory influence of dopamine of hypothalamic origin on prolactin secretion seems to be present in all taxa although its role is most important in mammals in which a regulatory releasing mechanism has not been identified to date (Figure 4).

\section{AUTHOR CONTRIBUTIONS}

All authors participated in the design of literature review, reading of relevant manuscripts, interpretation of the literature, and writing of the manuscript.

\section{FUNDING}

This work was supported by the Hungarian National Research, Development and Innovation Office OTKA K116538, OTKA K134221, NKFIH-4300-1/2017-NKP_17, NKFIH-2920-1/2016-VEKOP-2.3.-15, and NKFIH-6785-1/2016VEKOP-2.3.3-15 research grants, and Semmelweis University (783-3/2018/FEKUTSRAT) and Eötvös Loránd University Institutional Excellence Programs (NKFIH-1157-8/2019-DT). MC was supported by the János Bolyai Research Scholarship of the Hungarian Academy of Sciences and the UNKP-19-4-ELTE180 and UNKK-19-3-I-SE-93 New National Excellence Program of the Ministry for Innovation and Technology, Hungary.

Auperin, B., Rentier-Delrue, F., Martial, J. A., and Prunet, P. (1995). Regulation of gill prolactin receptors in tilapia (Oreochromis niloticus) after a change in salinity or hypophysectomy. J. Endocrinol. 145, 213-220. doi: 10.1677/joe.0. 1450213

Auriemma, R. S., Pirchio, R., De Alcubierre, D., Pivonello, R., and Colao, A. (2019). Dopamine agonists: from the 1970s to today. Neuroendocrinology 109, 34-41. doi: 10.1159/000499470

Bago, A. G., Dimitrov, E., Saunders, R., Seress, L., Palkovits, M., Usdin, T. B., et al. (2009). Parathyroid hormone 2 receptor and its endogenous ligand tuberoinfundibular peptide of 39 residues are concentrated in endocrine, viscerosensory and auditory brain regions in macaque and human. Neuroscience 162, 128-147. doi: 10.1016/j.neuroscience.2009. 04.054

Bakowska, J. C., and Morrell, J. I. (1997). Atlas of the neurons that express mrna for the long form of the prolactin receptor in the forebrain of the female rat. J. Comp. Neurol. 386, 161-177. doi: 10.1002/(sici)1096-9861(19970922)386: $2<161:$ :aid-cne1>3.0.co;2-\#

Bakowska, J. C., and Morrell, J. I. (2003). The distribution of mrna for the short form of the prolactin receptor in the forebrain of the female rat. Brain Res. Mol. Brain Res. 116, 50-58. doi: 10.1016/s0169-328x(03)00213-4

Bender, N., Taborsky, M., and Power, D. M. (2008). The role of prolactin in the regulation of brood care in the cooperatively breeding fish neolamprologus pulcher. J. Exp. Zool. A Ecol. Genet. Physiol. 309, 515-524. doi: 10.1002/jez.482 Bern, H. A., and Nicoll, C. S. (1968). The comparative endocrinology of prolactin. Recent Prog Horm Res 24, 681-720. 
Bhatt, R., Youngren, O., Kang, S., and El Halawani, M. (2003). Dopamine infusion into the third ventricle increases gene expression of hypothalamic vasoactive intestinal peptide and pituitary prolactin and luteinizing hormone beta subunit in the turkey. Gen. Comp. Endocrinol. 130, 41-47. doi: 10.1016/s0016-6480(02) 00533-6

Bjoro, T., Sand, O., Ostberg, B. C., Gordeladze, J. O., Torjesen, P., Gautvik, K. M., et al. (1990). The mechanisms by which vasoactive intestinal peptide (vip) and thyrotropin releasing hormone (trh) stimulate prolactin release from pituitary cells. Biosci. Rep. 10, 189-199. doi: 10.1007/bf01116578

Bole-Feysot, C., Goffin, V., Edery, M., Binart, N., and Kelly, P. A. (1998). Prolactin (prl) and its receptor: actions, signal transduction pathways and phenotypes observed in prl receptor knockout mice. Endocr. Rev. 19, 225-268. doi: 10.1210/ edrv.19.3.0334

Borba, V. V., Zandman-Goddard, G., and Shoenfeld, Y. (2019). Prolactin and autoimmunity: the hormone as an inflammatory cytokine. Best Pract. Res. Clin. Endocrinol. Metab. 33:101324. doi: 10.1016/j.beem.2019.101324

Bourque, C. W., and Oliet, S. H. (1997). Osmoreceptors in the central nervous system. Annu. Rev. Physiol. 59, 601-619. doi: 10.1146/annurev.physiol.59.1.601

Breves, J. P., Inokuchi, M., Yamaguchi, Y., Seale, A. P., Hunt, B. L., Watanabe, S., et al. (2016). Hormonal regulation of aquaporin 3: opposing actions of prolactin and cortisol in tilapia gill. J. Endocrinol. 230, 325-337. doi: 10.1530/joe-16-0162

Breves, J. P., McCormick, S. D., and Karlstrom, R. O. (2014). Prolactin and teleost ionocytes: new insights into cellular and molecular targets of prolactin in vertebrate epithelia. Gen. Comp. Endocrinol. 203, 21-28. doi: 10.1016/j.ygcen. 2013.12.014

Bridges, R. S., and Grattan, D. R. (2019). 30 years after: CNS actions of prolactin: sources, mechanisms and physiological significance. J. Neuroendocrinol. 31:e12669. doi: 10.1111/jne.12669

Bridges, R. S., Numan, M., Ronsheim, P. M., Mann, P. E., and Lupini, C. E. (1990). Central prolactin infusions stimulate maternal behavior in steroidtreated, nulliparous female rats. Proc. Natl. Acad. Sci. U.S.A. 87, 8003-8007. doi: 10.1073/pnas.87.20.8003

Bridges, R. S., Robertson, M. C., Shiu, R. P. C., Friesen, H. G., Stuer, A. M., and Mann, P. E. (1996). Endocrine communication between conceptus and mother: placental lactogen stimulation of maternal behavior. Neuroendocrinology 64, 57-64. doi: 10.1159/000127098

Brinca, L., Fuentes, J., and Power, D. M. (2003). The regulatory action of estrogen and vasoactive intestinal peptide on prolactin secretion in sea bream (sparus aurata, 1.). Gen. Comp. Endocrinol. 131, 117-125. doi: 10.1016/s0016-6480(02) 00628-7

Brown, R. S., Herbison, A. E., and Grattan, D. R. (2011). Differential changes in responses of hypothalamic and brainstem neuronal populations to prolactin during lactation in the mouse. Biol. Reprod. 84, 826-836. doi: 10.1095/ biolreprod.110.089185

Brown, R. S., Herbison, A. E., and Grattan, D. R. (2015). Effects of prolactin and lactation on a15 dopamine neurones in the rostral preoptic area of female mice. J. Neuroendocrinol. 27, 708-717. doi: 10.1111/jne. 12297

Brown, R. S., Kokay, I. C., Herbison, A. E., and Grattan, D. R. (2010). Distribution of prolactin-responsive neurons in the mouse forebrain. J. Comp. Neurol. 518, 92-102. doi: 10.1002/cne.22208

Brown, R. S., Piet, R., Herbison, A. E., and Grattan, D. R. (2012). Differential actions of prolactin on electrical activity and intracellular signal transduction in hypothalamic neurons. Endocrinology 153, 2375-2384. doi: 10.1210/en.20112005

Brown, R. S., Wyatt, A. K., Herbison, R. E., Knowles, P. J., Ladyman, S. R., Binart, N., et al. (2016). Prolactin transport into mouse brain is independent of prolactin receptor. FASEB J. 30, 1202-1210.

Brown, R. S. E., Aoki, M., Ladyman, S. R., Phillipps, H. R., Wyatt, A., Boehm, U., et al. (2017). Prolactin action in the medial preoptic area is necessary for postpartum maternal nursing behavior. Proc. Natl. Acad. Sci. U.S.A. 114, 10779-10784. doi: 10.1073/pnas.1708025114

Bu, G., Liang, X., Li, J., and Wang, Y. (2015). Extra-pituitary prolactin (prl) and prolactin-like protein (prl-1) in chickens and zebrafish. Gen. Comp. Endocrinol. 220, 143-153. doi: 10.1016/j.ygcen.2015.02.001

Buntin, J. D., Becker, G. M., and Ruzycki, E. (1991). Facilitation of parental behavior in ring doves by systemic or intracranial injections of prolactin. Horm. Behav. 25, 424-444. doi: 10.1016/0018-506x(91)90012-7
Buntin, J. D., and Buntin, L. (2014). Increased stat5 signaling in the ring dove brain in response to prolactin administration and spontaneous elevations in prolactin during the breeding cycle. Gen. Comp. Endocrinol. 200, 1-9. doi: 10.1016/j.ygcen.2014.02.006

Cabrera-Reyes, E. A., Limon-Morales, O., Rivero-Segura, N. A., Camacho-Arroyo, I., and Cerbon, M. (2017). Prolactin function and putative expression in the brain. Endocrine 57, 199-213. doi: 10.1007/s12020-017-1346-x

Campbell, G. S., Argetsinger, L. S., Ihle, J. N., Kelly, P. A., Rillema, J. A., and Carter$\mathrm{Su}$, C. (1994). Activation of jak2 tyrosine kinase by prolactin receptors in nb2 cells and mouse mammary gland explants. Proc. Natl. Acad. Sci. U.S.A. 91, 5232-5236. doi: 10.1073/pnas.91.12.5232

Carretero, J., Angoso, M., Rubio, M., Blanco, E. J., Sierra, E., Herrero, J. J., et al. (2006). In vitro immunoblockade of vip inhibits the proliferation of pituitary prolactin cells. Anat. Embryol. (Berl.) 211, 11-18. doi: 10.1007/s00429-0050058-9

Cave, B. J., Wakerley, J. B., Luckman, S. M., and Tortonese, D. J. (2001). Hypothalamic targets for prolactin: assessment of c-fos induction in tyrosine hydroxylase- and proopiomelanocortin-containing neurones in the rat arcuate nucleus following acute central prolactin administration. Neuroendocrinology 74, 386-395. doi: 10.1159/000054705

Chaiseha, Y., Youngren, O., Al-Zailaie, K., and El Halawani, M. (2003). Expression of $\mathrm{d} 1$ and $\mathrm{d} 2$ dopamine receptors in the hypothalamus and pituitary during the turkey reproductive cycle: colocalization with vasoactive intestinal peptide. Neuroendocrinology 77, 105-118. doi: 10.1159/000068649

Christensen, D., and Vleck, C. M. (2008). Prolactin release and response to vasoactive intestinal peptide in an opportunistic breeder, the zebra finch (Taeniopygia guttata). Gen. Comp. Endocrinol. 157, 91-98. doi: 10.1016/j.ygcen. 2008.04.013

Christian, H. C., Chapman, L. P., and Morris, J. F. (2007). Thyrotrophinreleasing hormone, vasoactive intestinal peptide, prolactin-releasing peptide and dopamine regulation of prolactin secretion by different lactotroph morphological subtypes in the rat. J. Neuroendocrinol. 19, 605-613. doi: 10. $1111 / \mathrm{j} .1365-2826.2007 .01567 . \mathrm{x}$

Clevenger, C. V., and Kline, J. B. (2001). Prolactin receptor signal transduction. Lupus 10, 706-718. doi: 10.1191/096120301717164949

Crowley, W. R. (2015). Neuroendocrine regulation of lactation and milk production. Compr. Physiol. 5, 255-291. doi: 10.1002/cphy.c140029

Cservenak, M., Bodnar, I., Usdin, T. B., Palkovits, M., Nagy, G. M., and Dobolyi, A. (2010). Tuberoinfundibular peptide of 39 residues is activated during lactation and participates in the suckling-induced prolactin release in rat. Endocrinology 151, 5830-5840. doi: 10.1210/en.2010-0767

Cservenak, M., Kis, V., Keller, D., Dimen, D., Menyhart, L., Olah, S., et al. (2017). Maternally involved galanin neurons in the preoptic area of the rat. Brain Struct. Funct. 222, 781-798. doi: 10.1007/s00429-016-1246-5

Cservenak, M., Szabo, E. R., Bodnar, I., Leko, A., Palkovits, M., Nagy, G. M., et al. (2013). Thalamic neuropeptide mediating the effects of nursing on lactation and maternal motivation. Psychoneuroendocrinology 38, 3070-3084. doi: 10.1016/j. psyneuen.2013.09.004

Cunha, A. A. P., Partridge, C. G., Knapp, R., and Neff, B. D. (2019). Androgen and prolactin manipulation induces changes in aggressive and nurturing behavior in a fish with male parental care. Horm. Behav. 116:104582. doi: 10.1016/j.yhbeh. 2019.104582

de Ruiter, A. J., Wendelaar Bonga, S. E., Slijkhuis, H., and Baggerman, B. (1986). The effect of prolactin on fanning behavior in the male three-spined stickleback, gasterosteus aculeatus 1. Gen. Comp. Endocrinol. 64, 273-283. doi: 10.1016/ 0016-6480(86)90014-6

Dobolyi, A., Cservenak, M., and Young, L. J. (2018). Thalamic integration of social stimuli regulating parental behavior and the oxytocin system. Front. Neuroendocrinol. 51:2. doi: 10.1016/j.yfrne.2018.05.002

Dobolyi, A., Dimitrov, E., Palkovits, M., and Usdin, T. B. (2012). The neuroendocrine functions of the parathyroid hormone 2 receptor. Front. Endocrinol. (Lausanne) 3:121. doi: 10.3389/fendo.2012.00121

Dobolyi, A., Irwin, S., Wang, J., and Usdin, T. B. (2006). The distribution and neurochemistry of the parathyroid hormone 2 receptor in the rat hypothalamus. Neurochem. Res. 31, 227-236. doi: 10.1007/s11064-005-9011-9

Dobolyi, A., and Leko, A. H. (2019). The insulin-like growth factor-1 system in the adult mammalian brain and its implications in central maternal adaptation. Front. Neuroendocrinol. 52:2. doi: 10.1016/j.yfrne.2018.12.002 
Dobolyi, A., Palkovits, M., Bodnar, I., and Usdin, T. B. (2003a). Neurons containing tuberoinfundibular peptide of 39 residues project to limbic, endocrine, auditory and spinal areas in rat. Neuroscience 122, 1093-1105. doi: 10.1016/ j.neuroscience.2003.08.034

Dobolyi, A., Palkovits, M., and Usdin, T. B. (2003b). Expression and distribution of tuberoinfundibular peptide of 39 residues in the rat central nervous system. J. Comp. Neurol. 455, 547-566. doi: 10.1002/cne.10515

Dobolyi, A., Palkovits, M., and Usdin, T. B. (2010). The tip39-pth2 receptor system: unique peptidergic cell groups in the brainstem and their interactions with central regulatory mechanisms. Prog. Neurobiol. 90, 29-59. doi: 10.1016/j. pneurobio.2009.10.017

Dohanics, J., Smith, M. S., Blackburn, R. E., and Verbalis, J. G. (1994). Osmotic inhibition of prolactin secretion in rats. J. Neuroendocrinol. 6, 291-298. doi: 10.1111/j.1365-2826.1994.tb00585.x

Dulac, C., O'Connell, L. A., and Wu, Z. (2014). Neural control of maternal and paternal behaviors. Science 345, 765-770. doi: 10.1126/science.1253291

Egli, M., Bertram, R., Sellix, M. T., and Freeman, M. E. (2004). Rhythmic secretion of prolactin in rats: action of oxytocin coordinated by vasoactive intestinal polypeptide of suprachiasmatic nucleus origin. Endocrinology 145, 3386-3394. doi: 10.1210/en.2003-1710

Everett, J. W. (1964). Central neural control of reproductive functions of the adenohypophysis. Physiol. Rev. 44, 373-431. doi: 10.1152/physrev.1964.44. 3.373

Exton, M. S., Kruger, T. H., Koch, M., Paulson, E., Knapp, W., Hartmann, U., et al. (2001). Coitus-induced orgasm stimulates prolactin secretion in healthy subjects. Psychoneuroendocrinology 26, 287-294. doi: 10.1016/s0306-4530(00) 00053-6

Faber, C. A., Dobolyi, A., Sleeman, M., and Usdin, T. B. (2007). Distribution of tuberoinfundibular peptide of 39 residues and its receptor, parathyroid hormone 2 receptor, in the mouse brain. J. Comp. Neurol. 502, 563-583. doi: $10.1002 / \mathrm{cne} .21330$

Fazekas, E. A., Morvai, B., Zachar, G., Dora, F., Szekely, T., Pogany, A., et al. (2020). Neuronal activation in zebra finch parents associated with reintroduction of nestlings. J. Comp. Neurol. 528, 363-379. doi: 10.1002/cne.24761

Fernandez-Valdivia, R., Mukherjee, A., Ying, Y., Li, J., Paquet, M., DeMayo, F. J., et al. (2009). The rankl signaling axis is sufficient to elicit ductal side-branching and alveologenesis in the mammary gland of the virgin mouse. Dev. Biol. 328, 127-139. doi: 10.1016/j.ydbio.2009.01.019

Fodor, A., Klausz, B., Pinter, O., Daviu, N., Rabasa, C., Rotllant, D., et al. (2012). Maternal neglect with reduced depressive-like behavior and blunted c-fos activation in brattleboro mothers, the role of central vasopressin. Horm. Behav. 62, 539-551. doi: 10.1016/j.yhbeh.2012.09.003

Freeman, M. E., Kanyicska, B., Lerant, A., and Nagy, G. (2000). Prolactin: structure, function, and regulation of secretion. Physiol. Rev. 80, 1523-1631. doi: 10.1152/ physrev.2000.80.4.1523

Fuentes, J., Brinca, L., Guerreiro, P. M., and Power, D. M. (2010). Prl and gh synthesis and release from the sea bream (Sparus auratus 1.) pituitary gland in vitro in response to osmotic challenge. Gen. Comp. Endocrinol. 168, 95-102. doi: 10.1016/j.ygcen.2010.04.005

Goffin, V., Shiverick, K. T., Kelly, P. A., and Martial, J. A. (1996). Sequence-function relationships within the expanding family of prolactin, growth hormone, placental lactogen, and related proteins in mammals. Endocr. Rev. 17, 385-410. doi: 10.1210/er.17.4.385

Gonzalez-Iglesias, A. E., Murano, T., Li, S., Tomic, M., and Stojilkovic, S. S. (2008). Dopamine inhibits basal prolactin release in pituitary lactotrophs through pertussis toxin-sensitive and -insensitive signaling pathways. Endocrinology 149, 1470-1479. doi: 10.1210/en.2007-0980

Grattan, D. R. (2015). The hypothalamo-prolactin axis. J. Endocrinol. 226, T101T122.

Grattan, D. R., and Szawka, R. E. (2019). Kisspeptin and prolactin. Semin. Reprod. Med. 37, 93-104.

Greenlee, M. M., Mitzelfelt, J. D., Duke, B. J., Al-Khalili, O., Bao, H. F., and Eaton, D. C. (2015). Prolactin stimulates sodium and chloride ion channels in a6 renal epithelial cells. Am. J. Physiol. Renal Physiol. 308, F697-F705.

Gunnet, J. W., and Freeman, M. E. (1983). The mating-induced release of prolactin: a unique neuroendocrine response. Endocr. Rev. 4, 44-61. doi: 10.1210/edrv4-1-44
Gunnet, J. W., and Freeman, M. E. (1984). Hypothalamic regulation of matinginduced prolactin release. Effect of electrical stimulation of the medial preoptic area in conscious female rats. Neuroendocrinology 38, 12-16. doi: 10.1159/ 000123859

Higo, S., Aikawa, S., Iijima, N., and Ozawa, H. (2015). Rapid modulation of hypothalamic kiss1 levels by the suckling stimulus in the lactating rat. J. Endocrinol. 227, 105-115. doi: 10.1530/joe-15-0143

Hirano, T. (1986). The spectrum of prolactin action in teleosts. Prog. Clin. Biol. Res. 205, 53-74.

Hiroi, J., and McCormick, S. D. (2012). New insights into gill ionocyte and ion transporter function in euryhaline and diadromous fish. Respir. Physiol. Neurobiol. 184, 257-268. doi: 10.1016/j.resp.2012.07.019

Holland, L. Z., Albalat, R., Azumi, K., Benito-Gutierrez, E., Blow, M. J., BronnerFraser, M., et al. (2008). The amphioxus genome illuminates vertebrate origins and cephalochordate biology. Genome Res. 18, 1100-1111.

Horseman, N. D., and Gregerson, K. A. (2014). Prolactin actions. J. Mol. Endocrinol. 52, R95-R106.

Ibarra, F., Crambert, S., Eklof, A. C., Lundquist, A., Hansell, P., and Holtback, U. (2005). Prolactin, a natriuretic hormone, interacting with the renal dopamine system. Kidney Int. 68, 1700-1707. doi: 10.1111/j.1523-1755.2005.00586.x

Jorgacevski, J., Stenovec, M., Kreft, M., Bajic, A., Rituper, B., Vardjan, N., et al. (2008). Hypotonicity and peptide discharge from a single vesicle. Am. J. Physiol. Cell Physiol. 295, C624-C631.

Kanematsu, S. (1980). Crop sac stimulation after electrochemical stimulation of the brain in the pigeon. Gen. Comp. Endocrinol. 42, 212-218. doi: 10.1016/00166480(80)90190-2

Katayama, Y., Sakamoto, T., Saito, K., Tsuchimochi, H., Kaiya, H., Watanabe, T., et al. (2018). Drinking by amphibious fish: convergent evolution of thirst mechanisms during vertebrate terrestrialization. Sci. Rep. 8:625.

Keeler, R., and Wilson, N. (1976). Vasopressin contamination as a cause of some apparent renal actions of prolactin. Can. J. Physiol. Pharmacol. 54, 887-890. doi: 10.1139/y76-124

Kennett, J. E., Poletini, M. O., and Freeman, M. E. (2008). Vasoactive intestinal polypeptide modulates the estradiol-induced prolactin surge by entraining oxytocin neuronal activity. Brain Res. 1196, 65-73. doi: 10.1016/j.brainres.2007. 12.061

Kline, J. B., and Clevenger, C. V. (2001). Identification and characterization of the prolactin-binding protein in human serum and milk. J. Biol. Chem. 276, 24760-24766. doi: 10.1074/jbc.m011786200

Kokay, I. C., Wyatt, A., Phillipps, H. R., Aoki, M., Ectors, F., Boehm, U., et al. (2018). Analysis of prolactin receptor expression in the murine brain using a novel prolactin receptor reporter mouse. J. Neuroendocrinol. 30:e12634. doi: $10.1111 /$ jne. 12634

Kosonsiriluk, S., Sartsoongnoen, N., Chaiyachet, O. A., Prakobsaeng, N., Songserm, T., Rozenboim, I., et al. (2008). Vasoactive intestinal peptide and its role in continuous and seasonal reproduction in birds. Gen. Comp. Endocrinol. 159, 88-97. doi: 10.1016/j.ygcen.2008.07.024

Kubokawa, K., Tando, Y., and Roy, S. (2010). Evolution of the reproductive endocrine system in chordates. Integr. Comp. Biol. 50, 53-62. doi: 10.1093/icb/ icq047

Kuwayama, T., Shimada, K., Saito, N., Ohkubo, T., Sato, K., Wada, M., et al. (1992). Effects of removal of chicks from hens on concentrations of prolactin, luteinizing hormone and oestradiol in plasma of brooding gifujidori hens. J. Reprod. Fertil. 95, 617-622. doi: 10.1530/jrf.0.0950617

Kwong, A. K., Ng, A. H., Leung, L. Y., Man, A. K., and Woo, N. Y. (2009). Effect of extracellular osmolality and ionic levels on pituitary prolactin release in euryhaline silver sea bream (Sparus sarba). Gen. Comp. Endocrinol. 160, 67-75. doi: 10.1016/j.ygcen.2008.10.024

Labella, F., Dular, R., Queen, G., and Vivian, S. (1975). Anterior pituitary hormone release in vitro inversely related to extracellular osmolarity. Endocrinology 96, 1559-1565. doi: 10.1210/endo-96-6-1559

Lam, K. S. (1991). Vasoactive intestinal peptide in the hypothalamus and pituitary. Neuroendocrinology 53(Suppl. 1), 45-51. doi: 10.1159/000125795

Le Tissier, P. R., Hodson, D. J., Martin, A. O., Romano, N., and Mollard, P. (2015). Plasticity of the prolactin (prl) axis: mechanisms underlying regulation of output in female mice. Adv. Exp. Med. Biol. 846, 139-162. doi: 10.1007/9783-319-12114-7_6 
Lea, R. W., and Sharp, P. J. (1991). Effects of presence of squabs upon plasma concentrations of prolactin and lh and length of time of incubation in ringdoves on "extended" incubatory patterns. Horm. Behav. 25, 275-282. doi: 10.1016/ 0018-506x(91)90001-x

Ledoux, J. E., Ruggiero, D. A., Forest, R., Stornetta, R., and Reis, D. J. (1987). Topographic organization of convergent projections to the thalamus from the inferior colliculus and spinal cord in the rat. J. Comp. Neurol. 264, 123-146. doi: 10.1002/cne.902640110

Lee, K. M., Kaneko, T., and Aida, K. (2006). Prolactin and prolactin receptor expressions in a marine teleost, pufferfish takifugu rubripes. Gen. Comp. Endocrinol. 146, 318-328. doi: 10.1016/j.ygcen.2005.12.003

Leko, A. H., Cservenak, M., and Dobolyi, A. (2017a). Suckling induced insulin-like growth factor-1 (igf-1) release in mother rats. Growth Horm. IGF Res. 37, 7-12. doi: 10.1016/j.ghir.2017.10.003

Leko, A. H., Cservenak, M., Szabo, E. R., Hanics, J., Alpar, A., and Dobolyi, A. (2017b). Insulin-like growth factor i and its binding protein-3 are regulators of lactation and maternal responsiveness. Sci. Rep. 7:3396.

Li, C., Chen, P., and Smith, M. S. (1999). Neural populations in the rat forebrain and brainstem activated by the suckling stimulus as demonstrated by cfos expression. Neuroscience 94, 117-129. doi: 10.1016/s0306-4522(99)00236-5

Lignot, J. H., Cutler, C. P., Hazon, N., and Cramb, G. (2002). Water transport and aquaporins in the european eel (Anguilla anguilla). Symp. Soc. Exp. Biol. 54, 49-59.

Lin, S. H., Miyata, S., Matsunaga, W., Kawarabayashi, T., Nakashima, T., and Kiyohara, T. (1998). Metabolic mapping of the brain in pregnant, parturient and lactating rats using fos immunohistochemistry. Brain Res. 787, 226-236. doi: 10.1016/s0006-8993(97)01484-4

Liu, N. A., Liu, Q., Wawrowsky, K., Yang, Z., Lin, S., and Melmed, S. (2006). Prolactin receptor signaling mediates the osmotic response of embryonic zebrafish lactotrophs. Mol. Endocrinol. 20, 871-880. doi: 10.1210/me.20050403

Lonstein, J. S., and Stern, J. M. (1997). Role of the midbrain periaqueductal gray in maternal nurturance and aggression: $\mathrm{C}$-fos and electrolytic lesion studies in lactating rats. J. Neurosci. 17, 3364-3378. doi: 10.1523/jneurosci.17-09-03364. 1997

Lonstein, J. S., and Stern, J. M. (1999). Effects of unilateral suckling on nursing behavior and c-fos activity in the caudal periaqueductal gray in rats. Dev. Psychobiol. 35, 264-275. doi: 10.1002/(sici)1098-2302(199912)35:4<264::aid$\operatorname{dev} 2>3.0 . \operatorname{co} ; 2-\mathrm{u}$

Lopez-Vicchi, F., Ladyman, S. R., Ornstein, A. M., Gustafson, P., Knowles, P., Luque, G. M., et al. (2020). Chronic high prolactin levels impact on gene expression at discrete hypothalamic nuclei involved in food intake. FASEB $\mathrm{J}$. 34, 3902-3914. doi: 10.1096/fj.201902357r

Lorenson, M. Y., and Jacobs, L. S. (1987). Osmotic pressure regulation of prolactin and growth hormone release from bovine secretory granules. Endocrinology 120, 365-372. doi: 10.1210/endo-120-1-365

Loìpez, M. A. C., Rodriìguez, J. L. R., and Garciìa, M. R. (2003). "Physiological and pathological hyperprolactinemia: can we minimize errors in the clinical practice?," in Prolactin, eds G. M. Nagy, and B. E. Toth, (London: IntechOpen).

Lv, C., Mo, C., Liu, H., Wu, C., Li, Z., Li, J., et al. (2018). Dopamine d2-like receptors (drd2 and drd4) in chickens: tissue distribution, functional analysis, and their involvement in dopamine inhibition of pituitary prolactin expression. Gene 651, 33-43. doi: 10.1016/j.gene.2018.01.087

Manzon, L. A. (2002). The role of prolactin in fish osmoregulation: a review. Gen. Comp. Endocrinol. 125, 291-310. doi: 10.1006/gcen.2001. 7746

March, J. B., Sharp, P. J., Wilson, P. W., and Sang, H. M. (1994). Effect of active immunization against recombinant-derived chicken prolactin fusion protein on the onset of broodiness and photoinduced egg laying in bantam hens. J. Reprod. Fertil. 101, 227-233. doi: 10.1530/jrf.0.1010227

Massaro, M., Setiawan, A. N., and Davis, L. S. (2007). Effects of artificial eggs on prolactin secretion, steroid levels, brood patch development, incubation onset and clutch size in the yellow-eyed penguin (Megadyptes antipodes). Gen. Comp. Endocrinol. 151, 220-229. doi: 10.1016/j.ygcen.2007. 01.034

Mayer-Gostan, N., and Hirano, T. (1976). The effects of transecting the ixth and xth cranial nerves on hydromineral balance in the eel anguilla anguilla. J. Exp. Biol. 64, 461-475.
McKinley, M. J., and Johnson, A. K. (2004). The physiological regulation of thirst and fluid intake. News Physiol. Sci. 19, 1-6. doi: 10.1152/nips.01470.2003

Morrissey, S. E., Newth, T., Rees, R., Barr, A., Shora, F., and Laycock, J. F. (2001). Renal effects of recombinant prolactin in anaesthetized rats. Eur. J. Endocrinol. 145, 65-71. doi: 10.1530/eje.0.1450065

Naef, L., and Woodside, B. (2007). Prolactin/leptin interactions in the control of food intake in rats. Endocrinology 148, 5977-5983. doi: 10.1210/en.2007-0442

Nagaishi, V. S., Cardinali, L. I., Zampieri, T. T., Furigo, I. C., Metzger, M., and Donato, J. Jr. (2014). Possible crosstalk between leptin and prolactin during pregnancy. Neuroscience 259, 71-83. doi: 10.1016/j.neuroscience.2013.11.050

Nagy, G. M., Arendt, A., Banky, Z., and Halasz, B. (1992). Dehydration attenuates plasma prolactin response to suckling through a dopaminergic mechanism. Endocrinology 130, 819-824. doi: 10.1210/en.130.2.819

Nagy, G. M., Bodnar, I., Banky, Z., and Halasz, B. (2005). Control of prolactin secretion by excitatory amino acids. Endocrine 28, 303-308. doi: 10.1385/endo: 28:3:303

Namken, S., Sinpru, P., Kamkrathok, B., Sartsoongnoen, N., and Chaiseha, Y. (2017). Role of vasoactive intestinal peptide during the transition from incubation behavior to rearing behavior in the female native thai chicken. Poult. Sci. 96, 3768-3774. doi: 10.3382/ps/pex180

Neill, J. D., and Nagy, G. M. (1994). "Prolactin secretion and its control," in Physiology of Reproduction, eds E. Knobil, and J. D. Neill, (New York: Raven Press), 1833-1860.

Nishimori, K., Young, L. J., Guo, Q., Wang, Z., Insel, T. R., and Matzuk, M. M. (1996). Oxytocin is required for nursing but is not essential for parturition or reproductive behavior. Proc. Natl. Acad. Sci. U.S.A. 93, 11699-11704. doi: 10.1073/pnas.93.21.11699

Nobata, S., Ando, M., and Takei, Y. (2013). Hormonal control of drinking behavior in teleost fishes; insights from studies using eels. Gen. Comp. Endocrinol. 192, 214-221. doi: 10.1016/j.ygcen.2013.05.009

Ocampo Daza, D., and Larhammar, D. (2018a). Evolution of the growth hormone, prolactin, prolactin 2 and somatolactin family. Gen. Comp. Endocrinol. 264, 94-112. doi: 10.1016/j.ygcen.2018.01.007

Ocampo Daza, D., and Larhammar, D. (2018b). Evolution of the receptors for growth hormone, prolactin, erythropoietin and thrombopoietin in relation to the vertebrate tetraploidizations. Gen. Comp. Endocrinol. 257, 143-160. doi: 10.1016/j.ygcen.2017.06.021

Ohkubo, T. (2017). Neuroendocrine control of broodiness. Adv. Exp. Med. Biol. 1001, 151-171. doi: 10.1007/978-981-10-3975-1_10

Olah, S., Cservenak, M., Keller, D., Fazekas, E. A., Renner, E., Low, P., et al. (2018). Prolactin-induced and neuronal activation in the brain of mother mice. Brain Struct. Funct. 223, 3229-3250. doi: 10.1007/s00429-018-1686-1

On, J. S., Chow, B. K., and Lee, L. T. (2015). Evolution of parathyroid hormone receptor family and their ligands in vertebrate. Front. Endocrinol. (Lausanne) 6:28. doi: 10.3389/fendo.2015.00028

Ouhtit, A., Morel, G., and Kelly, P. A. (1993). Visualization of gene expression of short and long forms of prolactin receptor in the rat. Endocrinology 133, 135-144. doi: 10.1210/endo.133.1.8319561

Palkovits, M., Usdin, T. B., Makara, G. B., and Dobolyi, A. (2010). Tuberoinfundibular peptide of 39 residues- immunoreactive fibers in the zona incerta and the supraoptic decussations terminate in the neuroendocrine hypothalamus. Neurochem. Res. 35, 2078-2085. doi: 10.1007/s11064-010-0292-2

Parker, S. L., Armstrong, W. E., Sladek, C. D., Grosvenor, C. E., and Crowley, W. R. (1991). Prolactin stimulates the release of oxytocin in lactating rats: evidence for a physiological role via an action at the neural lobe. Neuroendocrinology 53 , 503-510. doi: 10.1159/000125764

Peaker, M., Phillips, J. G., and Wright, A. (1970). The effect of prolactin on the secretory activity of the nasal salt-gland of the domestic duck (Anas platyrhynchos). J. Endocrinol. 47, 123-127. doi: 10.1677/joe.0.0470123

Phillipps, H. R., Yip, S. H., and Grattan, D. R. (2019). Patterns of prolactin secretion. Mol. Cell Endocrinol. 502:110679. doi: 10.1016/j.mce.2019.110679

Pi, X., and Voogt, J. L. (2000). Effect of suckling on prolactin receptor immunoreactivity in the hypothalamus of the rat. Neuroendocrinology 71 , 308-317. doi: 10.1159/000054551

Pi, X. J., and Grattan, D. R. (1999). Increased prolactin receptor immunoreactivity in the hypothalamus of lactating rats. J. Neuroendocrinol. 11, 693-705. doi: 10.1046/j.1365-2826.1999.00386.x 
Pickford, G. E., and Phillips, J. G. (1959). Prolactin, a factor in promoting survival of hypophysectomized killifish in fresh water. Science 130, 454-455. doi: 10. 1126/science.130.3373.454

Proudman, J. A., and Opel, H. (1988). Stimulation of prolactin secretion from turkey anterior pituitary cells in culture. Proc. Soc. Exp. Biol. Med. 187, 448-454. doi: 10.3181/00379727-187-42687

Radhakrishnan, A., Raju, R., Tuladhar, N., Subbannayya, T., Thomas, J. K., Goel, R., et al. (2012). A pathway map of prolactin signaling. J. Cell Commun. Signal. 6, 169-173.

Reynolds, J. D., Goodwin, N. B., and Freckleton, R. P. (2002). Evolutionary transitions in parental care and live bearing in vertebrates. Philos. Trans. $R$ Soc. Lond. B Biol. Sci. 357, 269-281. doi: 10.1098/rstb.2001.0930

Richard-Yris, M. A., Sharp, P. J., Wauters, A. M., Guemene, D., Richard, J. P., and Foraste, M. (1998). Influence of stimuli from chicks on behavior and concentrations of plasma prolactin and luteinizing hormone in incubating hens. Horm. Behav. 33, 139-148. doi: 10.1006/hbeh.1998.1444

Romano, N., Yip, S. H., Hodson, D. J., Guillou, A., Parnaudeau, S., Kirk, S., et al. (2013). Plasticity of hypothalamic dopamine neurons during lactation results in dissociation of electrical activity and release. J. Neurosci. 33, 4424-4433. doi: 10.1523/jneurosci.4415-12.2013

Romanov, M. N., Talbot, R. T., Wilson, P. W., and Sharp, P. J. (2002). Genetic control of incubation behavior in the domestic hen. Poult. Sci. 81, 928-931. doi: $10.1093 / \mathrm{ps} / 81.7 .928$

Rosenblatt, J. S. (2003). Outline of the evolution of behavioral and nonbehavioral patterns of parental care among the vertebrates: critical characteristics of mammalian and avian parental behavior. Scand. J. Psychol. 44, 265-271. doi: 10.1111/1467-9450.00344

Royle, N. J., Russell, A. F., and Wilson, A. J. (2014). The evolution of flexible parenting. Science 345, 776-781. doi: 10.1126/science.1253294

Rozenboim, I., Tabibzadeh, C., Silsby, J. L., and el Halawani, M. E. (1993). Effect of ovine prolactin administration on hypothalamic vasoactive intestinal peptide (vip), gonadotropin releasing hormone i and ii content, and anterior pituitary vip receptors in laying turkey hens. Biol. Reprod. 48, 1246-1250. doi: 10.1095/ biolreprod48.6.1246

Sage, M., and Bern, H. A. (1971). Cytophysiology of the teleost pituitary. Int. Rev. Cytol. 31, 339-376. doi: 10.1016/s0074-7696(08)60062-5

Saiardi, A., Bozzi, Y., Baik, J. H., and Borrelli, E. (1997). Antiproliferative role of dopamine: loss of $\mathrm{d} 2$ receptors causes hormonal dysfunction and pituitary hyperplasia. Neuron 19, 115-126. doi: 10.1016/s0896-6273(00)80352-9

Sakamoto, T., and McCormick, S. D. (2006). Prolactin and growth hormone in fish osmoregulation. Gen. Comp. Endocrinol. 147, 24-30. doi: 10.1016/j.ygcen.2005. 10.008

Salais-Lopez, H., Lanuza, E., Agustin-Pavon, C., and Martinez-Garcia, F. (2017). Tuning the brain for motherhood: prolactin-like central signalling in virgin, pregnant, and lactating female mice. Brain Struct. Funct. 222, 895-921. doi: 10.1007/s00429-016-1254-5

Sandra, O., Le Rouzic, P., Cauty, C., Edery, M., and Prunet, P. (2000). Expression of the prolactin receptor (tiprl-r) gene in tilapia oreochromis niloticus: tissue distribution and cellular localization in osmoregulatory organs. J. Mol. Endocrinol. 24, 215-224. doi: 10.1677/jme.0.0240215

Santos, C. R., Ingleton, P. M., Cavaco, J. E., Kelly, P. A., Edery, M., and Power, D. M. (2001). Cloning, characterization, and tissue distribution of prolactin receptor in the sea bream (Sparus aurata). Gen. Comp. Endocrinol. 121, 32-47. doi: $10.1006 /$ gcen.2000.7553

Sapsford, T. J., Kokay, I. C., Ostberg, L., Bridges, R. S., and Grattan, D. R. (2012). Differential sensitivity of specific neuronal populations of the rat hypothalamus to prolactin action. J. Comp. Neurol. 520, 1062-1077. doi: 10.1002/cne.22775

Sartsoongnoen, N., Kosonsiriluk, S., Prakobsaeng, N., Songserm, T., Rozenboim, I., Halawani, M. E., et al. (2008). The dopaminergic system in the brain of the native thai chicken, gallus domesticus: localization and differential expression across the reproductive cycle. Gen. Comp. Endocrinol. 159, 107-115. doi: 10. 1016/j.ygcen.2008.08.002

Sauve, D., and Woodside, B. (1996). The effect of central administration of prolactin on food intake in virgin female rats is dose-dependent, occurs in the absence of ovarian hormones and the latency to onset varies with feeding regimen. Brain Res. 729, 75-81. doi: 10.1016/s0006-8993(96)00 $227-2$
Scott, N., Prigge, M., Yizhar, O., and Kimchi, T. (2015). A sexually dimorphic hypothalamic circuit controls maternal care and oxytocin secretion. Nature 525, 519-522. doi: 10.1038/nature 15378

Seale, A. P., Watanabe, S., and Grau, E. G. (2012). Osmoreception: perspectives on signal transduction and environmental modulation. Gen. Comp. Endocrinol. 176, 354-360. doi: 10.1016/j.ygcen.2011.10.005

Shu, Y., Lou, Q., Dai, Z., Dai, X., He, J., Hu, W., et al. (2016). The basal function of teleost prolactin as a key regulator on ion uptake identified with zebrafish knockout models. Sci. Rep. 6:18597.

Sinpru, P., Sartsoongnoen, N., Rozenboim, I., Porter, T. E., El Halawani, M. E., and Chaiseha, Y. (2018). The effects of replacing eggs with chicks on mesotocin, dopamine, and prolactin in the native thai hen. Gen. Comp. Endocrinol. 263, 32-42. doi: 10.1016/j.ygcen.2018.04.013

Sjoeholm, A., Bridges, R. S., Grattan, D. R., and Anderson, G. M. (2011). Region-, neuron-, and signaling pathway-specific increases in prolactin responsiveness in reproductively experienced female rats. Endocrinology 152, 1979-1988. doi: 10.1210/en.2010-1220

Smiley, K. O. (2019). Prolactin and avian parental care: new insights and unanswered questions. Horm. Behav. 111, 114-130. doi: 10.1016/j.yhbeh.2019. 02.012

Smiley, K. O., and Adkins-Regan, E. (2016). Relationship between prolactin, reproductive experience, and parental care in a biparental songbird, the zebra finch (Taeniopygia guttata). Gen. Comp. Endocrinol. 232, 17-24. doi: 10.1016/j. ygcen.2015.11.012

Soares, M. J., Konno, T., and Alam, S. M. (2007). The prolactin family: effectors of pregnancy-dependent adaptations. Trends Endocrinol. Metab. 18, 114-121. doi: 10.1016/j.tem.2007.02.005

Specker, J. L., Kishida, M., Huang, L., King, D. S., Nagahama, Y., Ueda, H., et al. (1993). Immunocytochemical and immunogold localization of two prolactin isoforms in the same pituitary cells and in the same granules in the tilapia (Oreochromis mossambicus). Gen. Comp. Endocrinol. 89, 28-38. doi: 10.1006/ gcen.1993.1006

Suarez-Bregua, P., Cal, L., Canestro, C., and Rotllant, J. (2017). PTH reloaded: a new evolutionary perspective. Front. Physiol. 8:776. doi: 10.3389/fphys.2017. 00776

Suzuki, K., Koizumi, N., Hirose, H., Hokao, R., Takemura, N., and Motoyoshi, S. (2000). Changes in plasma arginine vasopressin concentration during lactation in rats. Comp Med 50, 277-280.

Szawka, R. E., Ribeiro, A. B., Leite, C. M., Helena, C. V., Franci, C. R., Anderson, G. M., et al. (2011). Kisspeptin regulates prolactin release through hypothalamic dopaminergic neurons. Endocrinology 151, 3247-3257. doi: 10.1210/en.20091414

Tacon, P., Baroiller, J. F., Le Bail, P. Y., Prunet, P., and Jalabert, B. (2000). Effect of egg deprivation on sex steroids, gonadotropin, prolactin, and growth hormone profiles during the reproductive cycle of the mouthbrooding cichlid fish oreochromis niloticus. Gen. Comp. Endocrinol. 117, 54-65. doi: 10.1006/ gcen.1999.7388

Takei, Y., Hiroi, J., Takahashi, H., and Sakamoto, T. (2014). Diverse mechanisms for body fluid regulation in teleost fishes. Am. J. Physiol. Regul. Integr. Comp. Physiol. 307, R778-R792.

Tindal, J. S., and Knaggs, G. S. (1969). An ascending pathway for release of prolactin in the brain of the rabbit. J. Endocrinol. 45, 111-120. doi: 10.1677/joe.0.0450111

Tindal, J. S., and Knaggs, G. S. (1972). Pathways in the forebrain of the rabbit concerned with the release of prolactin. J. Endocrinol. 52, 253-262. doi: 10. 1677 /joe.0.0520253

Tindal, J. S., and Knaggs, G. S. (1977). Pathways in the forebrain of the rat concerned with the release of prolactin. Brain Res. 119, 211-221. doi: 10.1016/ 0006-8993(77)90101-9

Tong, Z., Pitts, G. R., You, S., Foster, D. N., and El Halawani, M. E. (1998). Vasoactive intestinal peptide stimulates turkey prolactin gene expression by increasing transcription rate and enhancing mrna stability. J. Mol. Endocrinol. 21, 259-266. doi: 10.1677/jme.0.0210259

Usdin, T. B., Dobolyi, A., Ueda, H., and Palkovits, M. (2003). Emerging functions for tuberoinfundibular peptide of 39 residues. Trends Endocrinol. Metab. 14, 14-19. doi: 10.1016/s1043-2760(02)00002-4

Van Goor, F., Zivadinovic, D., Martinez-Fuentes, A. J., and Stojilkovic, S. S. (2001). Dependence of pituitary hormone secretion on the pattern of spontaneous 
voltage-gated calcium influx. Cell type-specific action potential secretion coupling. J. Biol. Chem. 276, 33840-33846. doi: 10.1074/jbc.m105386200

Voogt, J. L., Lee, Y., Yang, S., and Arbogast, L. (2001). Regulation of prolactin secretion during pregnancy and lactation. Prog. Brain Res. 133, 173-185. doi: 10.1016/s0079-6123(01)33013-3

Walker, C. D., Toufexis, D. J., and Burlet, A. (2001). Hypothalamic and limbic expression of crf and vasopressin during lactation: implications for the control of acth secretion and stress hyporesponsiveness. Prog. Brain Res. 133, 99-110. doi: 10.1016/s0079-6123(01)33008-x

Wan, X. P., Xie, P., Bu, Z., Zou, X. T., and Gong, D. Q. (2019). Prolactin induces lipid synthesis of organ-cultured pigeon crops. Poult. Sci. 98, 1842-1853. doi: $10.3382 /$ ps/pey540

Watanabe, H., Davis, J. B., Smart, D., Jerman, J. C., Smith, G. D., Hayes, P., et al. (2002). Activation of trpv4 channels (hvrl-2/mtrp12) by phorbol derivatives. J. Biol. Chem. 277, 13569-13577. doi: 10.1074/jbc.m200062200

Watanabe, S., Hirano, T., Grau, E. G., and Kaneko, T. (2009). Osmosensitivity of prolactin cells is enhanced by the water channel aquaporin-3 in a euryhaline mozambique tilapia (Oreochromis mossambicus). Am. J. Physiol. Regul. Integr. Comp. Physiol. 296, R446-R453.

Watanabe, S., Kaneko, T., and Aida, K. (2005). Aquaporin-3 expressed in the basolateral membrane of gill chloride cells in mozambique tilapia Oreochromis mossambicus adapted to freshwater and seawater. J. Exp. Biol. 208, 2673-2682. doi: $10.1242 /$ jeb.01684

Weber, G. M., Seale, A. P., Richman, I. N., Stetson, M. H., Hirano, T., and Grau, E. G. (2004). Hormone release is tied to changes in cell size in the osmoreceptive prolactin cell of a euryhaline teleost fish, the tilapia, Oreochromis mossambicus. Gen. Comp. Endocrinol. 138, 8-13. doi: 10.1016/j.ygcen.2004.04.006

Whittington, C. M., and Wilson, A. B. (2013). The role of prolactin in fish reproduction. Gen. Comp. Endocrinol. 191, 123-136. doi: 10.1016/j.ygcen.2013. 05.027

Witcher, J. A., and Freeman, M. E. (1985). The proestrous surge of prolactin enhances sexual receptivity in the rat. Biol. Reprod. 32, 834-839. doi: 10.1095/ biolreprod32.4.834
Wu, Z., Autry, A. E., Bergan, J. F., Watabe-Uchida, M., and Dulac, C. G. (2014). Galanin neurons in the medial preoptic area govern parental behaviour. Nature 509, 325-330. doi: 10.1038/nature13307

Xu, H., Shen, X., Zhou, M., Fang, M., Zeng, H., Nie, Q., et al. (2010). The genetic effects of the dopamine $\mathrm{d} 1$ receptor gene on chicken egg production and broodiness traits. BMC Genet. 11:17. doi: 10.1186/1471-215611-17

Yamaguchi, Y., Moriyama, S., Lerner, D. T., Grau, E. G., and Seale, A. P. (2016). Autocrine positive feedback regulation of prolactin release from tilapia prolactin cells and its modulation by extracellular osmolality. Endocrinology 157, 3505-3516. doi: 10.1210/en.2015-1969

Yip, S. H., Romano, N., Gustafson, P., Hodson, D. J., Williams, E. J., Kokay, I. C., et al. (2019). Elevated prolactin during pregnancy drives a phenotypic switch in mouse hypothalamic dopaminergic neurons. Cell Rep. 26, 17871799.

Youngren, O. M., el Halawani, M. E., Phillips, R. E., and Silsby, J. L. (1989). Effects of preoptic and hypothalamic lesions in female turkeys during a photoinduced reproductive cycle. Biol. Reprod. 41, 610-617. doi: 10.1095/biolreprod41.4.610

Youngren, O. M., el Halawani, M. E., Silsby, J. L., and Phillips, R. E. (1991). Intracranial prolactin perfusion induces incubation behavior in turkey hens. Biol. Reprod. 44, 425-431. doi: 10.1095/biolreprod44.3.425

Conflict of Interest: The authors declare that the research was conducted in the absence of any commercial or financial relationships that could be construed as a potential conflict of interest.

Copyright (c) 2020 Dobolyi, Oláh, Keller, Kumari, Fazekas, Csikós, Renner and Cservenák. This is an open-access article distributed under the terms of the Creative Commons Attribution License (CC BY). The use, distribution or reproduction in other forums is permitted, provided the original author(s) and the copyright owner(s) are credited and that the original publication in this journal is cited, in accordance with accepted academic practice. No use, distribution or reproduction is permitted which does not comply with these terms. 